\title{
Nanotechnology for Military Applications - a Survey of Recent Research in Military Technical Institute
}

\author{
Danica Simić1) \\ Milica Marjanovićc ${ }^{1)}$ \\ Maja Vitorović-Todorović1 ${ }^{1}$ \\ Sonja Bauk ${ }^{1)}$ \\ Dragana Lazić ${ }^{1)}$ \\ Aleksandra Samolov ${ }^{1)}$ \\ Novica Ristović1)
}

\begin{abstract}
Armies of powerful armed forces are already applying achievements of nanoscience and supporting researches in the field of nanotechnology. This paper surveys the recent research in the area of nanomaterials application in defence technologies, conducted in the Military Technical Institute in Belgrade, Serbia. This research covers the most important results obtained so far in the following areas: chemical biological, radiological and nuclear protection (CBRN protection), nanomodified polymer coatings and camouflage paints, composite structures for military aircraft, ballistic protection composites, and energetic materials. Researches gave promising results in all the named fields and encourage nanomaterials application in future.
\end{abstract}

Key words: nanotechnology, nanomatrials, nanoparticles, nanofibres, polymer coatings, military application, CBRN protection, ballistic protection, camouflage, energetic materials.

\section{Introduction}

$\mathrm{S}$ CIENCE and technology are advancing to the point that structuring matter at the nanometer scale is becoming routine. Nanotechnology is making revolutionary changes, bringing far-reaching consequences in many areas. Nanotechnology is the study and manipulation of the new properties that emerge as material dimensions are reduced to nanoscale $[1,2]$. Nanomaterials can be designed at the atomic level today, with more control over their properties for their desired purpose, mostly due to the large increase in surface area that results when individual particle-size decreases. Military scientists and engineers have an obligation to study these effects and apply them for the protection of their people.

All major forces are making efforts to research and develop nanotechnology- based materials and systems for military use. Asian and European countries do not run dedicated programs for defense nanotechnology research, with the exception of Sweden (Swedish Defense Nanotechnology Programme) [3]. Rather, they integrate several nanotechnology-related projects within their traditional defense-research structures, e.g. as materials research, electronic devices research, or biochemical protection research. However, in the U.S. military there is a tendency to exploit nanotechnology for future military use $[1,3,4]$. Institute for Soldier Nanotechnologies is constituted at Massachusetts Institute of Technology (MIT) in cooperation with the US Army and industry working together to discover technologies that dramatically advance soldier protection and survivability capabilities. They work on the projects in the area of soldier protection, battlefield care, and sensing: advanced multiscale methods for modeling of fracture in novel nanomaterials, shock mitigating and reinforcing molecular nanocomposites, design and testing of polymers for improved soldier protection, transformational nano-optoelectronic soldier capabilities, nanophotonics enhanced systems for the soldier, etc $[1,4]$. Nanotechnology offers a long list of potential alternatives for efficient, economical and sustainable power generation and storage. Lithium-air (Li-air) is a next-generation rechargeable battery technology with the potential to replace the current tech standards, lithium-ion (Li-ion), nickel metal-hydride (NiMh) and non-rechargeable lithium-manganese dioxide $\left(\mathrm{LiMnO}_{2}\right)$. Engineered nanomaterials and metamaterials that are stronger, lighter, have enhanced properties, that are more heat-resistant and more compact are becoming possible. Carbon nanotube/fullerene based materials have much higher strength-to-weight ratio than other currently used materials. Nanostructured materials can make lighter armor, and extremely strong building materials. Nanofibre based protective vests provide enhanced protection against projectiles.

American Department of Defense (DoD) was working a new class of powerful bombs that use nanometals such as nanoaluminum to create ultra-high detonation rate chemical explosives an order of magnitude more powerful than conventional bombs. Like nano techniques can be designed to deliver medicines to targeted locations within the human

\footnotetext{
1) Military Technical Institute (VTI), Ratka Resanovića 1, 11132 Belgrade, SERBIA

Correspondence to: Danica Simić; e-mail: simic_danica@yahoo.com
} 
body, bioterrorists could use similar techniques to release highly toxic substances to the most vulnerable or desired target areas of the body. One other direction is the development of a battle suit that dynamically provides protection, communication, mechanical enhancement and thermal management, compresses wounds and administers therapeutic drugs. Parallel to improvements in weaponry, equal improvements are developed in armor protection. Nanostructured materials can make lighter, stronger, and adaptive armor, for improved protection against projectiles. A patented invention called "Kryron" presents a practical application of nanomaterials in this purpose, a material made from an aluminum alloy combined with carbon nanotubes [5].

Regarding the funds for research in this area, a good example is the U.S. Department of Defense as a major investor, spending well over $30 \%$ of all federal investment dollars in nanotechnology [1, 3]. Proposed military nanotechology programs cover a wide range of applications to improve the performance of existing systems and materials and to provide new ones. Main areas of research are the explosives, biomedicine, biological and chemical sensors, nanowires and carbon nanotubes for nanoelectronics, gold nanocluster-based sensors and electronics, power generation and storage, nanometallics for armaments, nanocomposites and structural materials for vehicles, coatings, filters and fabrics, self decontaminating surfaces, energy-absorbing and mechanically active nanomaterials in clothing and body armor. These new materials will be a part of the future soldier's battlesuit $[3,4]$.

In the Military Technical Institute in Belgrade (VTI) there has been an established research in the field of nanomaterials application for defense technologies, covering several topics: CBRN protection, polymer composites, coatings, camouflage paints, metal surfaces protection from abrasion and friction, in structural and ballistic composites and in energetic materials [6-23].

Different nanoparticles can be used in these systems for improving their properties. In the presented research the following nanomaterials were used: nanoparticles of $\mathrm{TiO}_{2}$ and $\mathrm{SiO}_{2}$, spherical nanoparticles of aluminum, tungsten disulfide in the form of fullerene-like nanoparticles IF- $\mathrm{WS}_{2}$ and inorganic nanotubes INT-WS 2 . Nanoparticles of $\mathrm{TiO}_{2}$ and $\mathrm{SiO}_{2}$ are used to create self-decontaminated textile for use in military protective clothes, first of these two for their photocatalitic abilities and the second for their reinforcing effect. Also, $\mathrm{WS}_{2}$ nanoparticles and nanotubes are used in rubber-textile materials for CBRN protection, to enhance mechanical resistance of these materials [6-10]. Using $\mathrm{WS}_{2}$ nanoparticles and nanotubes as fillers in polymer coatings resulted in improvements of mechanical resistance and of camouflage performance, as well as in poly (vinyl butyral), PVB coatings on glass, in two-component polyurethane coating and in a two-component water-based paint for military camouflage protection [11-18]. The same nanostructures are used as a reinforcement of multilayer laminate composites based on aramid fabric and PVB for ballistic protection, as well as in carbon fibre/ epoxy composites for aircraft construction. Aluminum particles are used as a fuel component of Plastic Bonded explosives, PBX, in order to enhance their energetic performance.

Tungsten disulfide, among other transition-metal dichalcogenides $\left(\mathrm{MoS}_{2}, \mathrm{WS}_{2}, \mathrm{NbS}_{2}\right.$, etc.), due to their excellent mechanical properties, can be used for a wide range of applications, including aerospace and automotive technology, load bearing and release mechanisms, as solid lubricants, for corrosion protection, as reinforcement in composites etc [24-27]. In the form of inorganic fullerene-like particles, with unique morphology, spherical and closed structure, they possess a chemical inertness and a high elasticity. Due to these exceptional characteristics, inorganic fullerene-like particles, such as tungsten disulfide IF-WS $\mathrm{W}_{2}$, are recognized as promising materials and promising fillers of the composites and are extensively studied for their ability to control wetting, adhesion, lubrication on surfaces and interfaces, and to achieve good corrosion protection and wear resistance, thus, they may be used as an addition for different types of protective coatings [28, 29]. Multilayer tungsten disulfide nanotubes have shown outstanding shock resistance properties that are superior even of carbon nanotubes. $\mathrm{WS}_{2}$ is thermally stable and compatible with various systems, so incorporating them into a proper matrix may lead to composites with new properties: improved thermal, rheological, and mechanical properties, compared to their neat polymers. SEM images of these nanoparticles that were used in researches in the Military Technical Institute are shown in Figures 1 and 2.

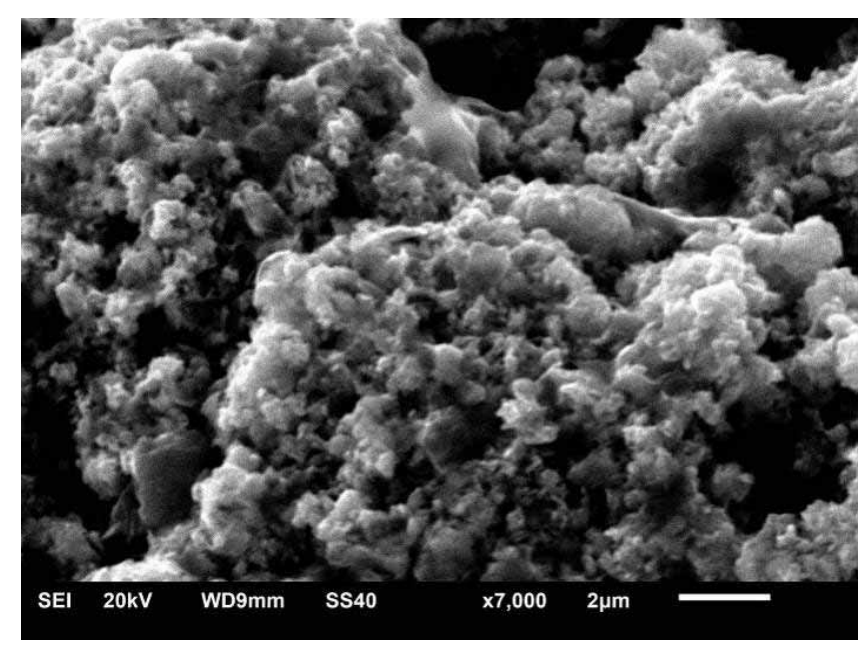

Figure 1. SEM image of IF-WS 2 , as received

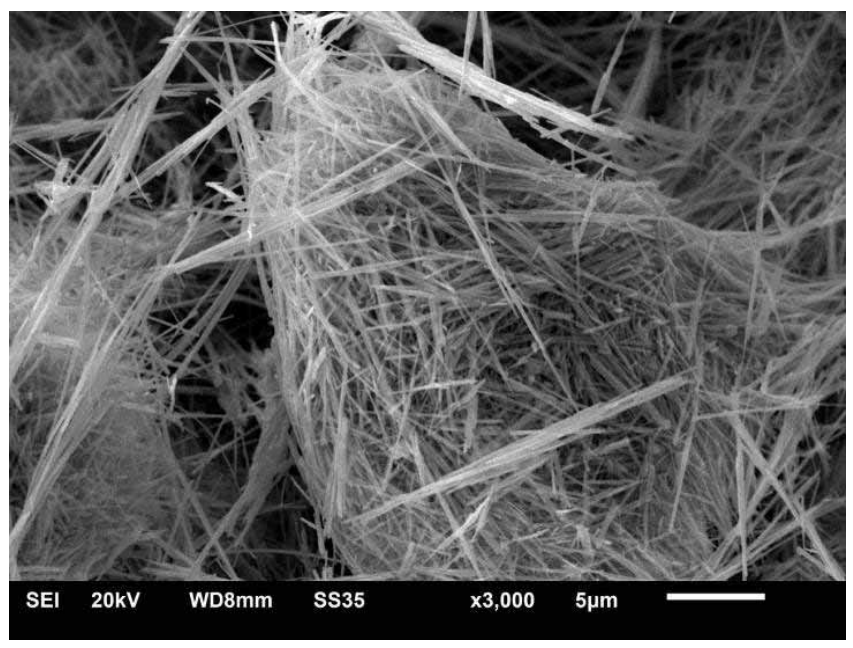

Figure 2. SEM image of INT-WS $\mathrm{W}_{2}$, as received

\section{Nanotechnologies in CBRN protection}

\section{Nanomodified textile materials for CBRN protection}

Filtration or insulating materials used for development of modern protective suits against chemical warfare agents (CWA) provide only a physical barrier against $\mathrm{CW}$ toxicants, so further steps of their post-use decontamination and 
adequate disposal are needed. Therefore, there is an increased need for the development of materials which not only provide physical barrier against CW agents, but will also degrade them to certain extent. Current research activities on materials for chemical and biological agent protection are directed toward design of the so-called "smart textiles", with antimicrobial and "self-decontaminating" properties. One way to obtain multifunctional textile materials which can degrade toxic chemicals and decompose organic matter is based on application of nanotechnologies, especially metal oxide nanoparticles with photocatalytic activities. $\mathrm{TiO}_{2}$ nanoparticles have proved to be the best for this purpose, because of their availability, low cost and low toxicity $[6,8]$. In order to develop self-decontaminating textiles, the surface of standard military textile (cotton-polyester, 50\%) was modified in the Military Technical Institute by deposition of $\mathrm{TiO}_{2}$ nanoparticles [8]. They can be easily synthesized by titanium tetraisopropoxide (TIP) hydrolysis, employed with variation in reaction conditions regarding temperature, precursor concentration and duration of the reaction [30, 31]. Ten $\mathrm{TiO}_{2}$ modified textile samples were produced by dipping the untreated textile into reaction mixtures with various subsequent treatments. Obtained samples showed satisfactory photocatalytic activity toward degradation of methyl orange, as a model compound, and the potential for detoxication of nerve agent VX ([2-(diisopropylamino)ethyl]-O-ethyl methylphosphonothioate), but severe degradation of mechanical properties (tearing strength and tensile strength) were observed. To preserve the satisfactory photocatalytic activity of $\mathrm{TiO}_{2}$ modified textile samples but to prevent the degradation of their mechanical properties, the $\mathrm{SiO}_{2}$ nanoparticles were used along with $\mathrm{TiO}_{2}$ in subsequent series of experiments. Several samples of $\mathrm{TiO}_{2} / \mathrm{SiO}_{2}$ treated textiles samples were obtained with variable photocatalytic activity and mechanical properties [6-10].

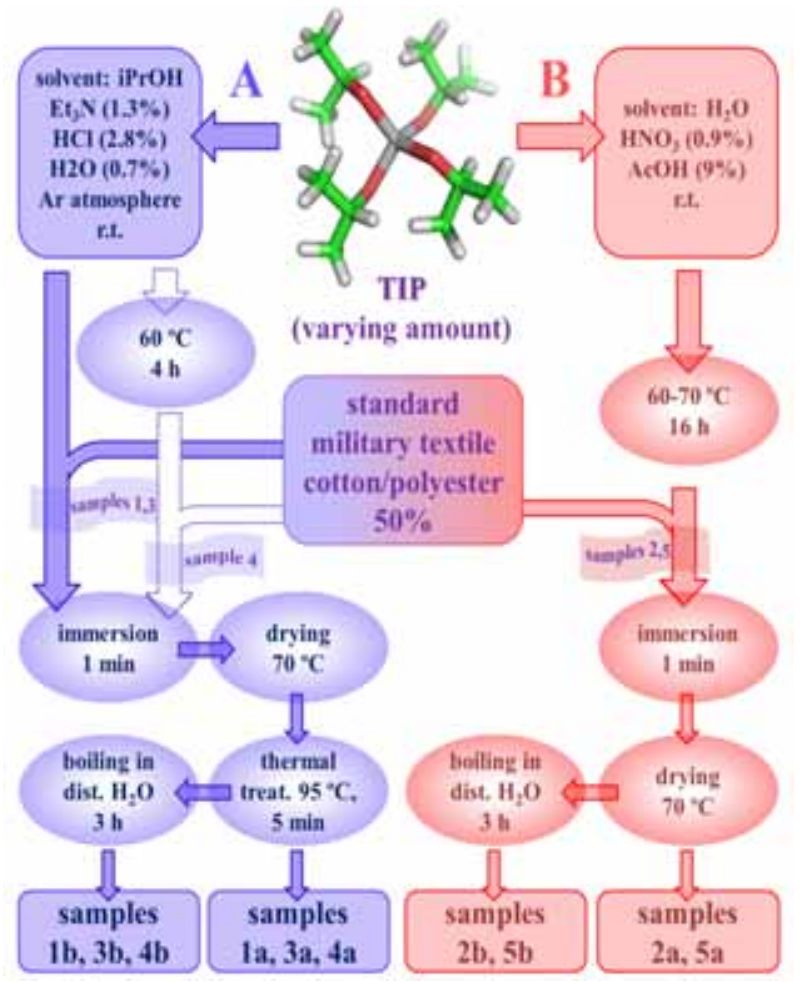

Figure 3. Scheme of different methods for preparing $\mathrm{TiO}_{2}$-coated textile samples

The investigated methods for the synthesis of $\mathrm{TiO}_{2}$ nanoparticles are schematically presented in Fig.4, along with different post treatments of $\mathrm{TiO}_{2}$ deposited textiles. Photocatalytic activity of the treated textiles was tested by degradation of organic dye, methyl orange (MeO) (Fig.3). The residual concentration of $\mathrm{MeO}$ was monitored spectrophotometrically, by the intensity of its absorption peak at $465 \mathrm{~nm}$ wavelength. The measurements were performed at different times after the initiation of photodegradation. The photocatalytic decolorization of $\mathrm{MeO}$ dye followed first-order reaction kinetics, so calculated values of the apparent firstorder rate constants $\left(k_{\text {app }}\right)$ permit a direct comparison of the photocatalytic efficiency of prepared samples (Table 1, Fig.4) [6]. The method B, hydrolysis of TIP in acidified water [31], proved to be superior comparing to the method A, which was performed in isopropanol, in the presence of the small amounts of water and stabilizer [30]. It is supposed that in the synthesis A formation of $\mathrm{TiO}_{2}$ nanocrystals was not completed, neither after subsequent treatment of the textile samples at $95^{\circ} \mathrm{C}$.

Table 1. Synthetic conditions and $k_{a p p}$ values for the tested samples

\begin{tabular}{|c|c|c|c||}
\hline Sample & TIP rel. amount & $T\left({ }^{\circ} \mathrm{C}\right)$, time $(\mathrm{h})$ & $k_{\text {app }}$ \\
\hline \hline 1a & 0.5 & r.t. & 1.67 \\
\hline 1b & 0.5 & r.t. & 4.74 \\
\hline 2a & 1 & 60.16 & 9.52 \\
\hline $2 \mathrm{~b}$ & 1 & 60.16 & 6.76 \\
\hline $3 \mathrm{a}$ & 1 & r.t. & 2.63 \\
\hline $3 \mathrm{~b}$ & 1 & r.t. & 5.68 \\
\hline $4 \mathrm{a}$ & 1 & 60.4 & 3.84 \\
\hline $4 \mathrm{~b}$ & 1 & 60.4 & 7.84 \\
\hline $5 \mathrm{a}$ & 0.5 & 60.16 & 6.79 \\
\hline $5 \mathrm{~b}$ & 0.5 & 60.16 & 7.17 \\
\hline
\end{tabular}

*r.t. - room temperature
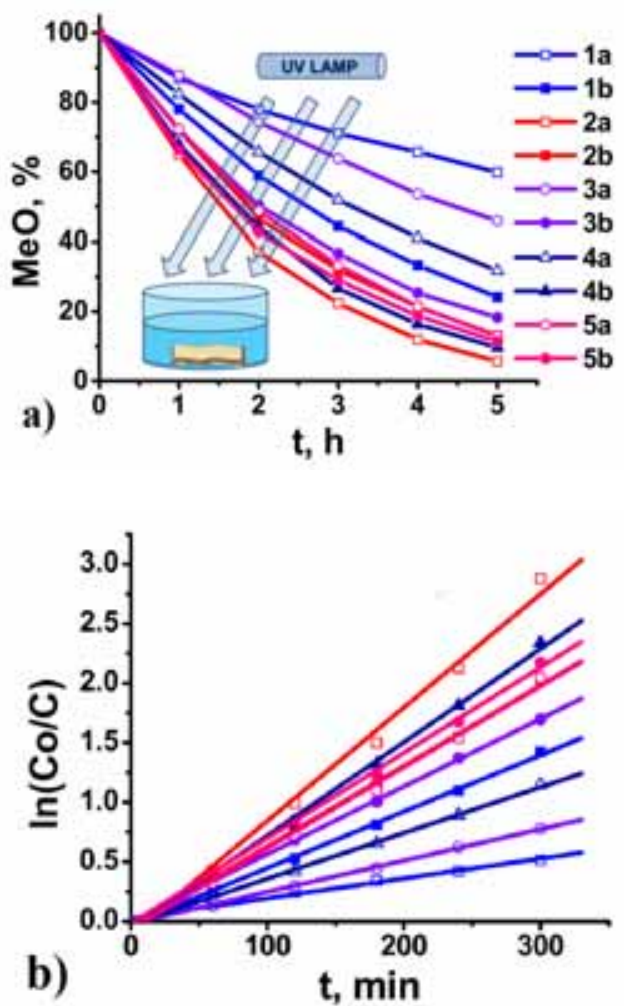

Figure 4. a) Photodecomposition kinetics of $\mathrm{MeO}$ in aqueous solution as a function of UV irradiation time for ten $\mathrm{TiO}_{2}$-coated textile samples, b) First order kinetic plots for the decomposition of $\mathrm{MeO}$ in the presence of $\mathrm{TiO}_{2}$ coated fabric samples

Textile sample $2 \mathrm{a}$ was used for nerve agent VX 
detoxication testing (Fig.6). Detection of VX by enzymatic AChE method was used to monitor residual toxicity of the solution. Photocatalytic potency of the sample toward VX was much lower than in $\mathrm{MeO}$ degradation testing. However, it should be noticed that applied analytical procedure is biological test which provides information on the overall toxicity that arises from all present AChE inhibiting compounds. The photocatalytic degradation of VX may produce a variety of organic intermediates, which can be even more toxic than the compound itself, so the results should actually depict the detoxication rather than the degradation kinetics. The fact is that anti-AChE behavior of photodegraded samples persistently decreased with the irradiation time, but reached only about $70 \%$ of the initial VX amount in non-irradiated starting solution. Although this result could be mainly attributed to the initial reaction conditions related to the low VX concentration, it is likely that better degradation efficiency could be also achieved through the optimization of the other reaction parameters for $\mathrm{TiO}_{2}$ nanoparticles synthesis.

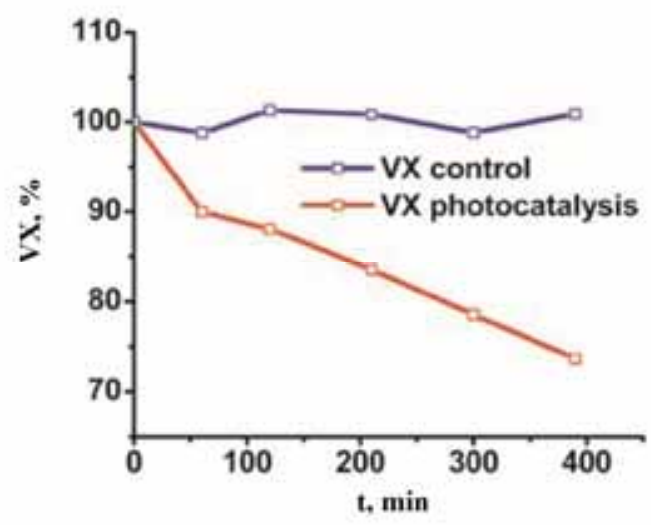

Figure 6. VX photodecomposition in the presence of $\mathrm{TiO}_{2}$-coated textile sample $2 \mathrm{a}$ as a function of UV irradiation time

Sulfur mustard simulant (2-CEES) was used in the test where the following apparatus was used: stainless steel vessel, quartz cap; a climatic chamber, with controlled $\mathrm{T}, \mathrm{p}$ and humidity. There was stable concentration of 2-CEES over the sample, constant flow of air $(10 \mathrm{ml} / \mathrm{s})$ below the sample. 2CEES passed through the sample and collected in Tenax tubes. Hexane extraction was performed and gas chromatography-mass spectrometry (GC-MS) analysis was done. Results are shown in Fig.7. Modest results were observed, comparing to $\mathrm{MeO}$ degradation, but harsh conditions of the method should be kept in mind, as well as the fact that fast flow rate does not allow effective adsorption.

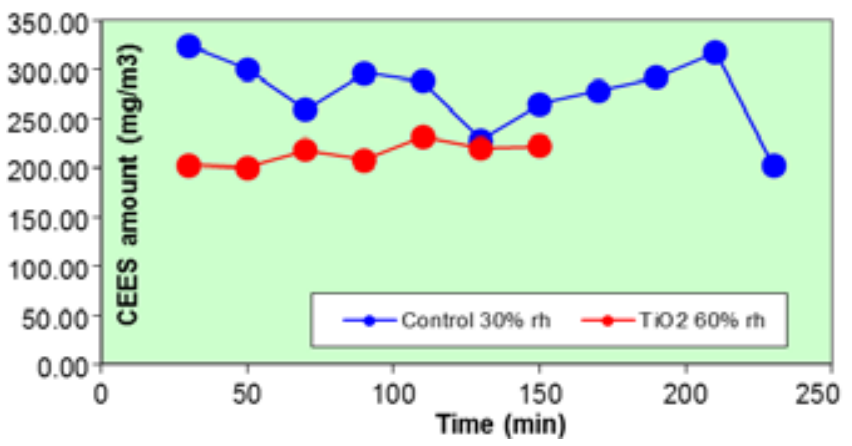

Figure 7. CEES permeation in time

Deposition of $\mathrm{TiO}_{2}$ nanoparticles on the textile substrates considerably diminishes their mechanical properties: tearing strength, tensile strength and elongation at fracture. This effect is more pronounced with the sample $1 \mathrm{a}$, since that sample is treated at $95^{\circ} \mathrm{C}$ in the oven, while the sample $2 \mathrm{a}$ is not subjected to this kind of the thermal treatment (Table 2).

Table 2. Mechanical properties of the tested textile samples

\begin{tabular}{|c|c|c|c|c|}
\hline \multicolumn{2}{|c|}{ Sample } & $\begin{array}{c}\text { Tearing strength } \\
{[N]}\end{array}$ & $\begin{array}{c}\text { Tensile strength } \\
{[N]}\end{array}$ & $\begin{array}{c}\text { Elongation } \\
{[\%]}\end{array}$ \\
\hline \multirow{3}{*}{ untreated } & warp & 49.21 & 1494.60 & 21.36 \\
\cline { 2 - 5 } & weft & 35.97 & 804.60 & 17.27 \\
\hline \multirow{2}{*}{ 1a } & warp & 27.07 & 890.70 & 28.60 \\
\cline { 2 - 5 } & weft & 19.99 & 715.30 & 24.03 \\
\hline \multirow{2}{*}{ 2a } & warp & 37.18 & 1015.60 & 24.21 \\
\cline { 2 - 5 } & weft & 25.31 & 780.21 & 21.17 \\
\hline
\end{tabular}

In order to preserve mechanical properties, we first pretreated textile samples with commercially available $\mathrm{SiO}_{2}$ nanoparticles and then treated them as samples $1 \mathrm{a}$ and $2 \mathrm{a}$ in the previous set of experiments. These samples are designated as $6 a$ and $7 \mathrm{a}$ (Table 3 ).

Table 3. Mechanical properties of the tested textile samples reinforced with $\mathrm{SiO}_{2}$

\begin{tabular}{|c|c|c|c|c|c|}
\hline \multicolumn{2}{|c|}{ Sample } & $\begin{array}{l}\text { Tearing strength } \\
{[\mathrm{N}]}\end{array}$ & $\begin{array}{l}\text { Tensile strength } \\
{[\mathrm{N}]}\end{array}$ & $\begin{array}{l}\text { Elong. } \\
{[\%]}\end{array}$ & $K_{\text {app }}$ \\
\hline \multirow{2}{*}{ 1a } & warp & 27.07 & 890.70 & 28.60 & \multirow{2}{*}{1.67} \\
\hline & weft & 19.99 & 715.30 & 24.03 & \\
\hline \multirow{2}{*}{$2 \mathrm{a}$} & warp & 37.18 & 1015.60 & 24.21 & \multirow{2}{*}{9.52} \\
\hline & weft & 25.31 & 780.21 & 21.17 & \\
\hline \multirow{2}{*}{$6 a$} & warp & 31.04 & 1050.23 & 25.15 & \multirow{2}{*}{1.58} \\
\hline & weft & 23.50 & 920.15 & 21.42 & \\
\hline \multirow{2}{*}{$7 \mathrm{a}$} & warp & 42.35 & 1215.50 & 23.12 & \multirow{2}{*}{8.92} \\
\hline & weft & 29.16 & 1015.20 & 19.15 & \\
\hline
\end{tabular}

The method based on the hydrolysis of TIP in water at very low $\mathrm{pH}$, prove to be superior, since treatment of the textile with nano $\mathrm{TiO}_{2}$ sol obtained by this synthetic procedure gave samples with far better photocatalytic activity. Nevertheless, treatment of the textiles by both types of nano $\mathrm{TiO}_{2}$ sols diminishes their mechanical properties. The ability of $\mathrm{TiO}_{2}$ to decompose $\mathrm{CW}$ agents is promising although further improvements in terms of efficacy are needed.

\section{Nanomodified rubber materials for CBRN protection}

The final treatment of rubber materials incorporated in the CBRN protection (protective clothing, socks and masks) and textile material processing (external layer of the filtering protective suit) was also investigated, and a comparative analysis of the physical-mechanical (tensile force, intermittent elongation and maximum force) and protective (protection time) characteristics of the obtained samples of the material was done [32]. The aim of the test is to determine the protection time of rubber or rubberized textile materials treated with $\mathrm{SiO}_{2}$ and $\mathrm{WS}_{2}$ nanoparticles and a comparative analysis with corresponding samples not treated with these 
nanoparticles. The butyl rubber material embedded in the CBRN mask for protection of face and respiratory organs. CBRN Protective cover is treated with IF-WS $\mathrm{W}_{2}$ nanoparticles and its physical and mechanical properties are monitored. Also, the same material surface was treated with nanoparticles IF-WS 2 and $\mathrm{SiO}_{2}$ and the time of protection of such materials was monitored. With $\mathrm{SiO}_{2}$ nanoparticles, surface treatment of the rubberized fabric was done, while the $\mathrm{WS}_{2}$ nanoparticles were directly added to the rubber itself. Physico-mechanical properties of the obtained samples were tested according to SRPS F.S2.017: 1958 and the protective properties of the obtained samples were tested according to SORS 6701/04. The preparation of samples of rubber mixtures was carried out on a laboratory blade. From the prepared samples of rubber mixtures, the production of samples of rubber vulcanized fabric for CBRN mask for protection of face and respiratory organs was realized. Rubber mixture samples were tested for physical mechanical properties in Trayal Corporation's laboratory. The values of the physical mechanical characteristics are shown in Table 4.

Table 4. Physico-mechanical properties of samples of untreated and treated materials with $\mathrm{WS}_{2}$ nanoparticles

\begin{tabular}{|c||c|c|c|c|c|c||}
\hline \multirow{2}{*}{ Characteristics } & \multicolumn{6}{|c||}{ Butyl rubber compound with different \% $\mathrm{WS}_{2}$} \\
& $0 \% *$ & $0.05 \%$ & $0.075 \%$ & $0.1 \%$ & $0.3 \%$ & $0.5 \%$ \\
\cline { 2 - 7 } & $0 \%$ manticles \\
\hline \hline Hardness, ${ }^{0}$ sh & $46-49$ & 47 & 47 & 47 & 47 & 48 \\
\hline Break strength, MPa & $\begin{array}{c}8.5- \\
10.4\end{array}$ & 10.3 & 12.9 & 12.1 & 11.4 & 12 \\
\hline Break elongation, \% & $\begin{array}{c}741- \\
909\end{array}$ & 846 & 934 & 918 & 930 & 894 \\
\hline
\end{tabular}

Based on the comparative results of the physical mechanical properties of butyl rubber without nanoparticles and butyl rubber with different $\%$ of nanoparticles, it can be concluded that the butyl rubber composition with $0.075 \%$ has the best physical mechanical properties. In case of this rubber, this is not so significant, as in the material for CBRN Protective cover, the carrier of physical mechanical characteristics is fabric, unlike the brombutyl rubber compound for CBRN Mask for protection of face and respiratory organs where it is the carrier of the physical mechanical characteristics of the tire. Also, testing of protective characteristics on the samples of rubberized vulcanized fabrics for Protective cover was done in VTI, while the results of the tests are shown in Table 5.

Table 5. Time of protection of untreated and treated samples of materials with nanoparticles $\mathrm{WS}_{2}$ at $25^{\circ} \mathrm{C}$.

\begin{tabular}{|c|c|c|}
\hline Sample/ $\% \mathrm{WS}_{2}$ & $\begin{array}{c}\text { Time of protection } \\
\text { at } 25^{\circ} \mathrm{C}, \min \end{array}$ & Required \\
\hline 0 & 287 & \multirow{6}{*}{$>120 \mathrm{~min}$} \\
\hline 0.050 & 202 & \\
\hline 0.075 & 202 & \\
\hline 0.100 & 323 & \\
\hline 0.300 & 323 & \\
\hline 0.500 & 323 & \\
\hline
\end{tabular}

According to the results shown in Table 5, the protection time for the action of the drops of the sulfur mustard at $25^{\circ} \mathrm{C}$, for samples containing a higher percentage of nanoparticles $\mathrm{WS}_{2}(0.1$ to $0.5 \%)$, was slightly longer compared to other low-content samples $\mathrm{WS}_{2}$, as well as in relation to the untreated sample.

\section{Nanomodified polymers and coatings}

A detailed analysis of the possibility of preparing PVB/IF$\mathrm{WS}_{2}$ composites was conducted. PVB is a thermoplastic polymer with excellent properties, widely used for protection of safety glass, in metal primers and different types of protective coatings, temporary binders, in ballistic protection $[16,33]$. PVB is a tough polymer with excellent flexibility, broad compatibility with modifying resins and additives, non toxic and low odor, good adhesion to many substrates and strong binding, impact resistance, good tensile strength and elasticity, freezing and aging resistance, well soluble in alcohols and many other organic solvents, fast drying, fast solvent release and low solvent retention, good film formation, transparent and colorless.

After preliminary physico-chemical examinations, effect of nanoparticles addition on thermal, mechanical and rheological behavior of $\mathrm{PVB} / \mathrm{WS}_{2}$ was studied [15-18]. Detailed investigation was conducted of the effects of using different solvents in preparation of $\mathrm{PVB} / \mathrm{IF}-\mathrm{WS}_{2}$ nanocomposite - PVB was dissolved in ethanol, isopropanol, n-butanol and ethyl acetate. IF-WS 2 nanoparticles were added to these PVB solutions and dispersed by different deagglomeration techniques. Samples were dried and thin films were obtained (Fig.8).

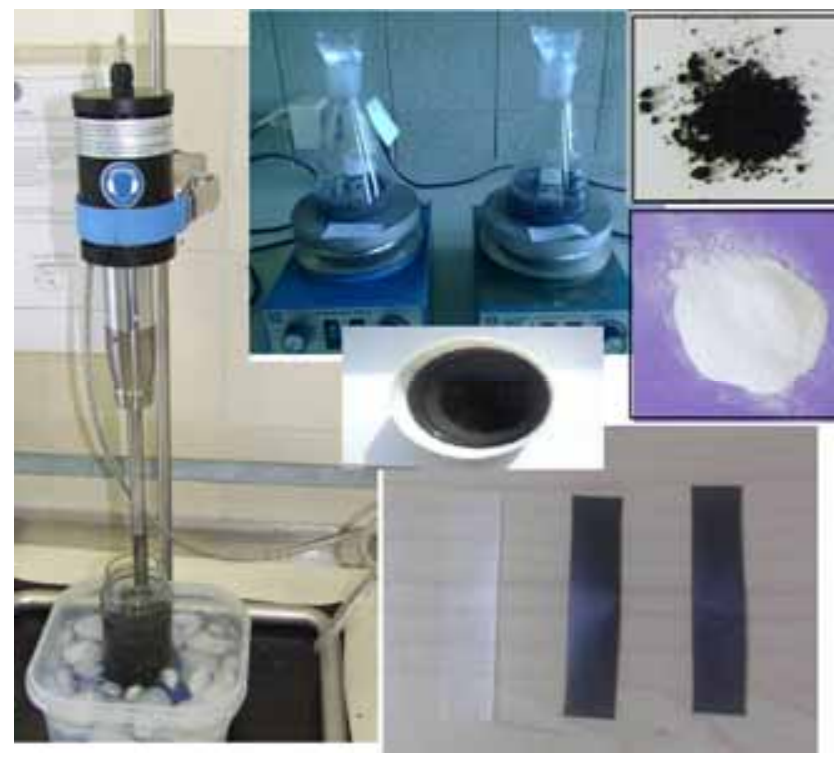

Figure 8. $\mathrm{PVB} / \mathrm{WS}_{2}$ samples preparation

The reinforcing effect of $\mathrm{IF}_{-} \mathrm{WS}_{2}$ is examined by determining hardness, reduced modulus of elasticity and coefficient of friction, by comparative nanoindentation and nanoscratch tests [16], in terms of different solvents applied in preparation of the samples, mode of stirring and different contents of IF-WS .

Nanomechanical and tribological properties are examined for the samples prepared using ethanol as a solvent, considering DSC and particle size analysis (PSA) results. Indentation hardness and reduced elastic modulus are increased after adding of nano-IF-WS $\mathrm{W}_{2}$. Adding $2 \mathrm{wt} \%$ of IF$\mathrm{WS}_{2}$ caused increase of glass transition temperature $\left(T_{g}\right)$ from $60.78^{\circ} \mathrm{C}$ to, $67.65^{\circ} \mathrm{C}$, increase of reduced elastic modulus (Er) for $122.4 \%$ and indentation hardness $(\mathrm{H})$ increase $168.2 \%$, as well as friction coefficient reduced for $48 \%$. Also, various solvents might be used for the purpose of incorporation of nanoparticles in the polymer, so it has been found that some of them are more convenient than others, and it has also been confirmed that PVB is compatible with this nanofiller [16, 
17]. Microcalorimetry compatibility analysis method was applied to examine the possible interactions between the constituents of the composite, using the heat flow calorimeter LKB Biocompatibility monitor. All spontaneous chemical and physical processes are associated with heat effects. Monitoring the flow of heat may be used to estimate interactions between different materials in touch, or study their compatibility. Samples (nanoparticles, PVB powder, PVB dissolved in ethanol and 2-propanol, and the mixtures of nanoparticles with pure or dissolved PVB) were heated for 456 hours at $75^{\circ} \mathrm{C}$. The released heat in time is compared with reference value, which represents the sum of the heat released when these materials are heated separately. Based on the results of measurements, the energy released per unit of mass for examined materials is determined, separately and for mixtures thereof. The coefficient of compatibility, D, is calculated, as a relative measure of interaction between the tested materials, and the value of D for IF- $\mathrm{WS}_{2}$ in mixture with pure $\mathrm{PVB}$, it was closer to the value of $\mathrm{D}$ for $\mathrm{PVB}$ dissolved in ethanol, than to the value of D for 2-propanol. The values of released energy were very similar for PVB powder and for PVB dissolved in ethanol while there was a significant difference in released energy for PVB dissolved in 2-propanol [17].

The glass transition temperature $\left(T_{g}\right)$ of the prepared thin film samples was determined by Differential Scanning Calorimetry - using DSC Q20 (TA Instruments) and Table 6 shows glass transition temperature for PVB with different particles contents and different deagglomeration techniques. us-ultrasonic deagglomeration, ms-magnetic stirrer

Table 6. DSC results $\left(\mathrm{T}_{\mathrm{g}},{ }^{\circ} \mathrm{C}\right)$ for different concentrations of IF-WS $\mathrm{W}_{2}$

\begin{tabular}{|c|c|}
\hline Sample & $\mathrm{T}_{\mathrm{g}},{ }^{\circ} \mathrm{C}$ \\
\hline 1 wt.\% IF-WS 2 / PVB/2-propanol us, $600 \mathrm{~W}$ & 57.87 \\
\hline 2 wt.\% IF-WS $/$ PVB/2-propanol us, $600 \mathrm{~W}$ & 60.91 \\
\hline 1 wt.\% IF-WS $/$ PVB/2-propanol ms & 61.63 \\
\hline 2 wt.\% IF-WS $2 /$ PVB/2-propanol ms & 62.37 \\
\hline 1 wt. $\%$ IF-WS $2 /$ PVB/etanol us, $300 \mathrm{~W}$ & 61.27 \\
\hline 2 wt. $\%$ IF-WS $2 /$ PVB/etanol us, $300 \mathrm{~W}$ & 67.65 \\
\hline
\end{tabular}

It may be observed that ultrasonic deagglomeration at 300 $\mathrm{W}$ is the optimum method, and that $\mathrm{T}_{\mathrm{g}}$ rises for the samples with higher content of nanoparticles.

The effect of IF-WS $\mathrm{W}_{2}$ on viscoelastic properties of the chosen samples has been examined using Dynamic Mechanical Thermal Analysis (DMTA) using the Modular Compact Rheometer MCR-302 (Anton Paar GmbH). DMTA tests have included strain amplitude sweep tests, in order to determine the linear viscoelastic range (LVR) of the tested samples. The temperature ramp test involves measurements of the storage and loss moduli and the loss factor over a specified temperature range at constant strain (or stress) amplitude and constant frequency. In temperature range from $20^{\circ} \mathrm{C}$ to $120^{\circ} \mathrm{C}$ the rheological parameters of the viscoelastic properties of the prepared composites were observed: the storage modulus $\left(G^{\prime}\right)$, loss modulus $\left(G^{\prime \prime}\right)$ as a function of temperature for the studied composites, and the loss factor, $\tan (\delta)=G^{\prime \prime} / G^{\prime}$. The glass transition temperature $(T g)$, determined by the dynamic mechanical measurements, was estimated as the temperature at which the loss factor, $\tan (\delta)$ reached its maximum value. Detailed discussion of the obtained results is given in previous publications [17, 19] and the results for $T_{g}$ are given in Table 7 .
Table 7. $T_{g}$ of the tested samples

\begin{tabular}{|c|c|c||}
\hline Sample & $\tan (\delta)_{\max }$ & $T_{g}\left[{ }^{\circ} \mathrm{C}\right]$ \\
\hline \hline PVB B60H/EtOH & 0.464 & 64.01 \\
\hline PVB B60H/EtOH/1 wt.\% WS 2 & 0.466 & 65.78 \\
\hline PVB B60H/EtOH/2 wt.\% $\mathrm{WS}_{2}$ & 0.407 & 67.35 \\
\hline
\end{tabular}

DMA results are in accordance with the previous methods of examination of composite materials. At the temperatures below $\mathrm{Tg}$, the storage modulus is higher for the samples with nanoparticles due to the reinforcement effect of the particles [16].

Tensile properties of thin films of PVB and of composites $\mathrm{PVB} / 3$ wt.\% IF-WS 2 and $\mathrm{PVB} / 0.3$ wt. INT-WS 2 are determined according to the appropriate ASTM standard [69]. Table 8 shows the results of testing the tensile properties of $\mathrm{PVB} / \mathrm{WS}_{2}$ thin films, including average values of maximum load $\left(F_{\max }\right)$, maximum elongation at break and tensile strength at break.

Table 8. Tensile properties of $\mathrm{PVB} / \mathrm{WS}_{2}$ thin films

\begin{tabular}{|c|c|c|c|}
\hline Sample & $F_{\max }[\mathrm{kN}]$ & $\begin{array}{c}\text { Max elongation } \\
{[\mathrm{mm}]}\end{array}$ & $\begin{array}{c}\text { Tensile strength } \\
{[\mathrm{MPa}]}\end{array}$ \\
\hline \hline $\mathrm{PVB}$ & 85.17 & 7.73 & 35.49 \\
\hline PVB/IF-WS & 94.42 & 6.13 & 39.34 \\
\hline PVB/INT-WS & 102.50 & 6.67 & 42.71 \\
\hline
\end{tabular}

It is evident from the results that the addition of tungsten disulfide nanostructures has enhanced mechanical resistance of the composite films, especially with addition of nanotubes: $20.3 \%$ increase of maximum force and tensile strength regarding neat $\mathrm{PVB}$.

The obtained results encourage the use of poly(vinyl butyral)/tungsten disulfide nanocomposite as a material of improved thermo-mechanical properties, that might find further application in many areas, and especially as antifriction material and as a coating or interlayer material of improved thermo-mechanical resistance. Currently researches are being conducted of spectrophotometric properties (reflectance and transmittance) of PVB thin films applied on glass plates, in order to consider the possibility of applying these coatings as protective layers on glass surfaces for military vehicles, and primary results indicate that this kind of glass coating has even camouflage properties in the visible spectra.

\section{Nanomodified military camouflage paints}

Coatings used in military should also have protective and camouflage protection functions. In VTI a possibility was investigated of using $\mathrm{WS}_{2}$ nanostructures as a filler in a twocomponent black polyurethane coating (PUR black, PUR b) and in a two-component water-based dark green paint (PUR dark green, PUR dg) for military camouflage protection and the properties of paints with and without nanoparticles were compared and analyzed, regarding the requirements of military standards concerning paint coatings. An accent has been put on examination of mechanical and chemical resistance of these paints, having in mind that this kind of coatings are often used in severe conditions of exploitation. In the end, the effect of IF-WS ${ }_{2}$ nanoparticles on spectrophotometric properties, i.e. on the camouflage ability of paints is examined [11-14].

Paints from the manufacturer PITURA, Belgrade, were used. Nanoparticles were added and dispersed in paint by 
ultrasonic irradiation. The paints were applied to standard steel plates, and dried, for examinations of chemical resistance to aggressive media and of the following physicalmechanical properties: hardness, flexibility, elasticity, abrasion resistance, resistance to steel balls impact and stickness. Camouflage properties were also examined - IR reflection and colorimetry. Significant improvements of mechanical resistance to abrasion and steel balls impact, as well as hardness, have been achieved. The persistence of the examined camouflage paints in different aggressive media was tested. The steel plates with the applied paints were immersed in different liquids and dried afterwards. The liquids were: water, sodium-chloride water solution (3.5 wt.\%), hydrocarbons mixture ( 80 vol.\% of isooctane and 20 vol. $\%$ of benzene), mineral oil (according to JUS TP.9 standard). After spending the required time in all these media, the steel plates were taken out, dried and observed in order to compare the appearance of the coatings after the exposure to aggressive solutions. Samples with nanoreinforcement have satisfied the criteria for resistance to all the applied aggressive media [14].

The comparative results of mechanical properties that are most affected by the addition of nanoreinforcement additive are presented in Table 9.

Table 9. Results of physical-mechanical examinations

\begin{tabular}{|c|c|c|c|c|c|c|c|}
\hline \multirow[b]{2}{*}{ Properties } & \multicolumn{2}{|c|}{$\begin{array}{l}\text { Standard } \\
\text { method }\end{array}$} & \multirow[b]{2}{*}{$\begin{array}{l}\text { Required } \\
\text { quality }\end{array}$} & \multicolumn{4}{|c|}{ Sample/results } \\
\hline & $\begin{array}{c}\text { SORS } \\
1634\end{array}$ & $\begin{array}{c}\text { SORS } \\
1564\end{array}$ & & PUR b & $\left|\begin{array}{c}\text { PUR b } \\
+ \\
\text { 1wt.\% } \\
\text { IF-WS }\end{array}\right|$ & $\begin{array}{c}\text { PUR } \\
\text { dg }\end{array}$ & $\begin{array}{c}\begin{array}{c}\text { PUR dg } \\
+ \\
0.5 \text { wt. } \% \\
\text { IF-WS }\end{array} \\
\end{array}$ \\
\hline $\begin{array}{l}\text { Hardness, s } \\
\text { (Kenig pen- } \\
\text { dulum) }\end{array}$ & 6.19 . & 4.7. & $>80$ & 90.0 & 97.0 & 101.6 & 109.0 \\
\hline $\begin{array}{c}\text { Resistance } \\
\text { to steel balls } \\
\text { impact }\end{array}$ & 6.20 . & 4.8. & \begin{tabular}{|c|} 
Needs to re- \\
sist 4500 \\
steel balls
\end{tabular} & $\begin{array}{c}+ \\
(5000)\end{array}$ & $\begin{array}{c}+ \\
(9500)\end{array}$ & $\left.\begin{array}{c}+ \\
(6000)\end{array}\right)$ & $\begin{array}{c}+ \\
(7500)\end{array}$ \\
\hline $\begin{array}{c}\text { Abrasion re- } \\
\text { sistance, } \\
\text { lit./ } \mu \mathrm{m}\end{array}$ & 6.22 . & 4.9. & \begin{tabular}{|}
0.1 lit. mul- \\
tiplied with \\
the thickness \\
of the coat- \\
ing
\end{tabular} & 1lit. & 1lit. & 5lit. & $>6$ lit. \\
\hline
\end{tabular}

It was observed that both paints, with and without nanoparticles, have good technological - application characteristics. Regarding the physical-mechanical resistance, the sample containing nanofiller has improved behavior. Stickness, elasticity and flexibility of both samples have met the requirements of the standards.

Hardness is superior for the sample containing IF-WS 2 . Resistance to steel balls impact was far better for the sample with nanoparticles. According to the standard, it is necessary that the coating applied on a steel plate resists the impact of 4500 steel balls, and, as shown in the table, PUR black with nanoparticles resisted the impact of 9500 balls - twice as much as the sample without nanoparticles. PUR dark green resisted the impact of 7500 balls.

Abrasion resistance is tested using a defined granulation of sand falling from defined height. The amount of sand for each coating sample is defined regarding the thickness of the tested coating, as liters of sand per layer thickness, multiplied with 0.1. In this research, for PUR black paint, both samples have failed, but for the comparison, the appearances of the samples after the same amount of sand are taken (after 1 liter of sand). It has been shown that the sample with nanoparticles has better abrasion resistance. The fact that both tested samples have failed this test may be a consequence of the paint layer thickness. For PUR dark green the samples with IF-WS ${ }_{2}$ have also shown better abrasion resistance, although both samples have met the required criteria of the standard. Figure 9 shows the appearance of the samples with and without nanoparticles, after the same amount of sand. In this case, it is the amount of 5 liters of sand, after which the surface of the coating without nanoparticles has been degraded.
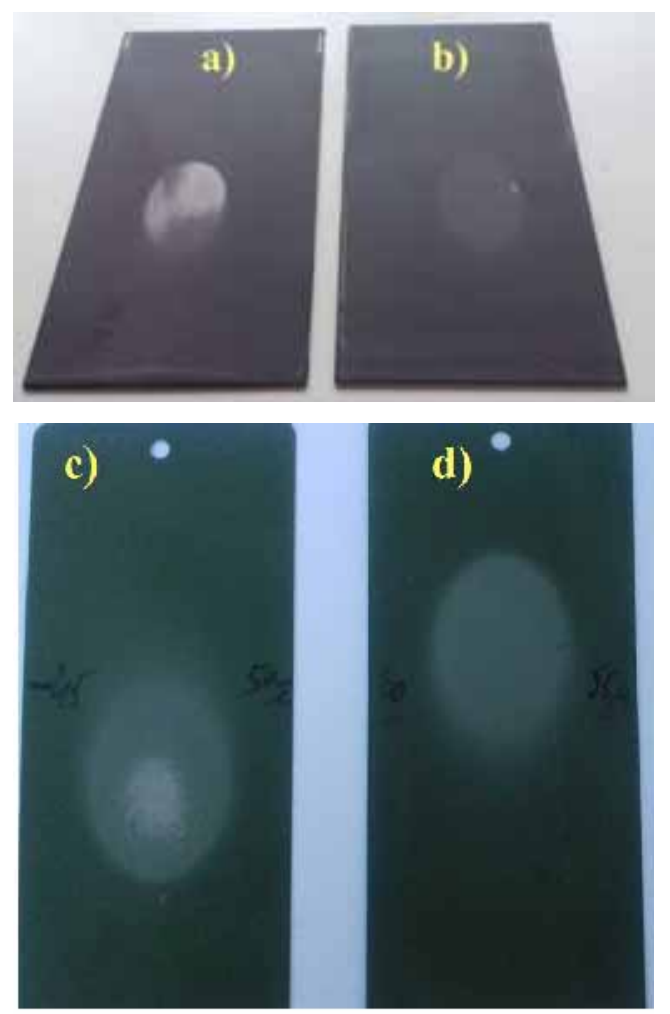

Figure 9. Abrasion resistance test: a) PUR b, b) PUR b + 1 wt. $\%$ IF-WS $_{2}$, c) PUR dg, d) PUR dg + 0.5 wt. $\%$ IF-WS 2

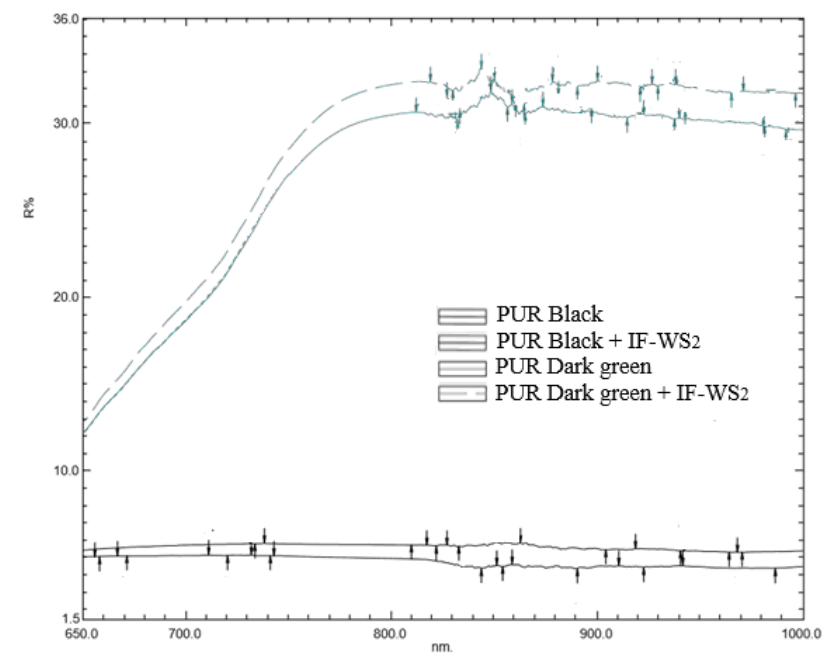

Figure 10. Dependency graph for diffuse reflection in the range between 650$1000 \mathrm{~nm}$ for the PUR black and for the PUR dark green (with and without nanoparticles)

The spectrophotometric measurements were conducted using the UV/VIS/NIR spectrophotometer Shimadzu UV 3600 with an integrating sphere. The reflectance was measured in the visible and near-infrared area of the electromagnetic spectrum $(650-1000 \mathrm{~nm})$, while color coordinates were measured in a visible part of the 
electromagnetic spectrum $(380-780 \mathrm{~nm})$. Fig.10 shows dependency graphs for diffuse reflection as the function of wavelength in the area of 650-1000 $\mathrm{nm}$ for the tested black and dark green tone, with and without nanoparticles. According to the Serbian military standard for values of diffuse reflection in the visible-near infra-red region for the black and dark green tone, SORS 7511, all of the dyed samples have good and acceptable camouflage behavior in the given area of electromagnetic spectrum. Moreover, the greater the reflectance value the better camouflage protection is, so in these terms for black tone, we would suggest usage of dye with nanoparticles. There is no significant difference in the reflectance curve behavior for dark green tone regarding both types of dyes (with or without nanoparticles).

In these terms another test has been performed and color coordinates have been measured. The results are presented in Table 10.

Table 10. Color coordinates defined in CIE system for both samples

\begin{tabular}{|c||c|c|c|c|c|c||}
\hline \multicolumn{1}{|c||}{} & \multicolumn{3}{c|}{ PUR black } & \multicolumn{3}{c|}{ PUR dark green } \\
\hline \hline Color coordinates & $L^{*}$ & $a^{*}$ & $b^{*}$ & $L^{*}$ & $a^{*}$ & $b^{*}$ \\
\hline With nanoparticles & 27.09 & 0.48 & 0.11 & 39.09 & -5.74 & 10.86 \\
\hline Without nanoparticles & 26.28 & 0.40 & 0.10 & 38.86 & -5.96 & 10.86 \\
\hline
\end{tabular}

The main characteristic these data provide is so called $\Delta \mathrm{E}$ difference which is a number calculated from the equation:

$$
\Delta E=\sqrt{\Delta L^{* 2}+\Delta a^{* 2}+\Delta b^{* 2}}
$$

where $\Delta L^{*}, \Delta a^{*}$ and $\Delta b^{*}$ are differences between two given coordinates values. If the $\Delta E$ is less than 1 , the difference between two paints is not visible to the observer's eye. For these samples $\Delta E=0.81$ for black tone and $\Delta E=0.32$ for dark green tone were calculated. So, the observer's eye cannot see the difference between two black tone samples neither for two dark green samples.

Further researches are planned with the paints of other colors of the camouflage system, as well as with other types of organic coatings.

\section{Nanoreinforced composites for ballistic protection}

Composite materials for ballistic protection are mostly based on fibers of high toughness and tensile strength, like aramid fabrics, impregnated with a thermoplastic or thermosetting polymer, or their combination [19, 20, 34, 35], often a combination of phenolic resin with poly (vinyl butyral), PVB. In order to achieve additional reinforcement of ballistic composite systems new technologies are developed. One of the ways to enhance protective performance of these composites is to add nanofillers of different properties and structures and tungsten disulfide is among them [36-39].

In the research conducted in VTI nanoparticles and nanotubes of tungsten disulfide were applied as a reinforcement of composites for personal ballistic protection based on aramid fabric and polymer matrix [19-22]. Laminated composites of improved mechanical properties were prepared using aramid fabric coated with phenolic resin, poly (vinyl butyral) and nanoparticles of IF-WS 2 , ultrasonically dispersed in ethanol, keeping the processing parameters (temperature, pressure and the duration of pressing) at defined values. Samples were then cut and prepared for thermo-mechanical and ballistic testing (Fig.11).

The quality of aramid fabrics impregnation with
$\mathrm{PVB} /$ phenolic resin/IF-WS 2 , and the nanoparticles dispersion were analyzed by scanning electron microscope with energy dispersive spectrometer. SEM analysis showed good dispersion of IF-WS 2 particles and certain degree of remained agglomeration of the filler. EDS analysis (energy dispersive X-ray spectrometer) and element mapping has showed good spatial distribution of IF$\mathrm{WS}_{2}$. Optical microscope images and SEM/EDS analysis confirmed that aramid fabric is well impregnated with the system phenolic resin/PVB/IF-WS 2 [19-22].

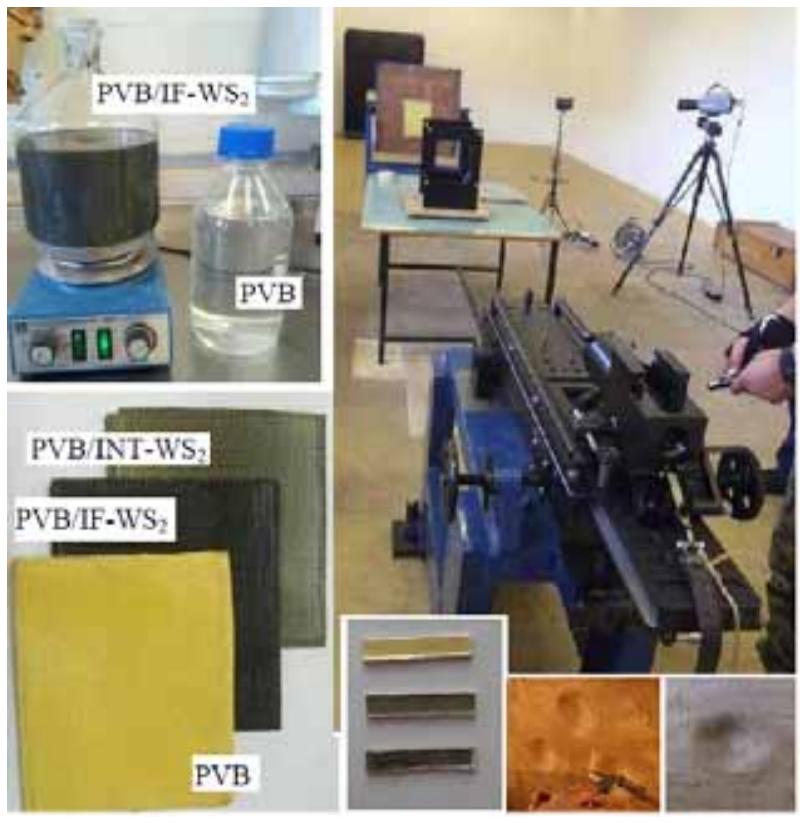

Figure 11. Preparation and examination of ballistic composite samples

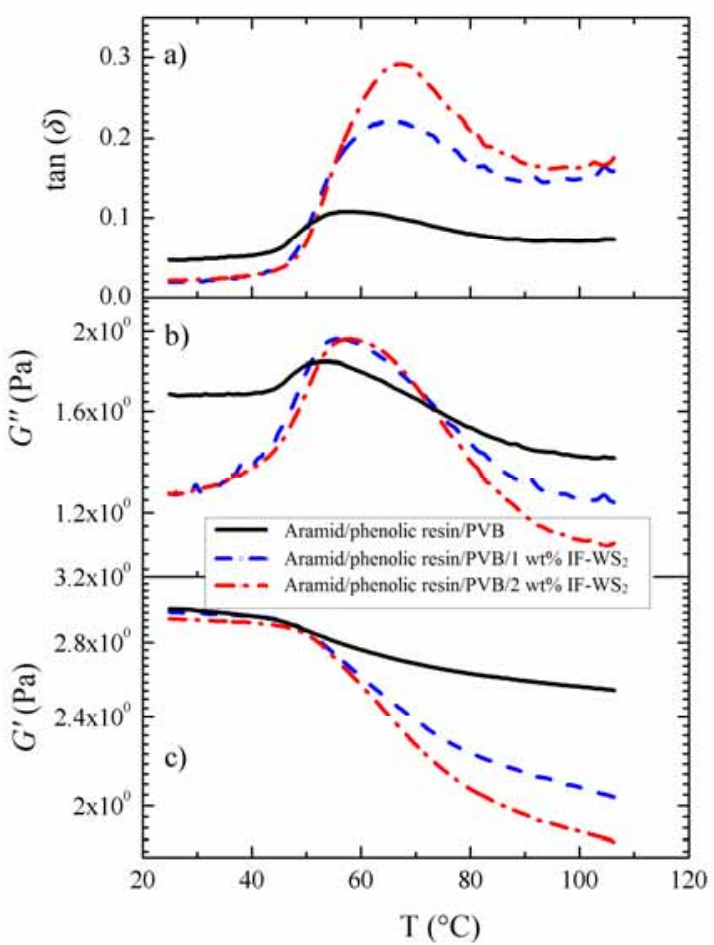

Figure 12. Temperature dependences of a) loss factor $\tan (\delta)$, b) loss modulus $\left(G^{\prime \prime}\right)$ and c) storage modulus $\left(G^{\prime}\right)$ for the tested composites

The effect of adding $\mathrm{WS}_{2}$ on thermo-rheological and elastic properties of the composites has been examined using Dynamic Mechanical Thermal Analysis (DMTA). After determination of linear viscoelastic region in the strain sweep test, a level of strain is chosen at which all three tested 
composite configurations would be correctly tested in examination of temperature and frequency dependence [20]. In temperature range from $20^{\circ} \mathrm{C}$ to $120^{\circ} \mathrm{C}$ the properties of the prepared composite were observed: the storage modulus and loss modulus as a function of temperature for the studied composites, and the mechanical loss factor (Fig.12).

Storage and loss modulus decreased with temperature increase, due to softening of the polymer matrix at higher temperatures. The loss modulus curves reach higher maxima for higher particles content. There was a shift in the glass transition towards higher temperatures with higher nanoparticles content, because of the limited mobility of the polymer molecules at the interface. Higher glass transition temperatures are observed for the samples containing higher content of IF-WS 2 nanoparticles (Table 11).

Table 11. DMTA results: glass transition temperatures for maximum peaks of $\tan (\delta)$.

\begin{tabular}{|c|c|c||}
\hline Composite sample & $\tan (\delta)_{\max }$ & $\mathrm{T}_{\mathrm{g}}\left({ }^{\circ} \mathrm{C}\right)$ \\
\hline \hline Aramid/phenolic resin/PVB & 0.108 & 57.25 \\
\hline Aramid/phenolic resin/PVB/1 wt\% IF-WS & 0.223 & 65.07 \\
\hline Aramid/phenolic resin/PVB/2 wt $\%$ IF-WS & 0.292 & 67.22 \\
\hline
\end{tabular}

The ability of tested composites to absorb impact energy is examined through impact toughness tests using Charpy impact tester [20]. Charpy impact test results are given in Table 12. Higher impact toughness result was achieved for the sample with

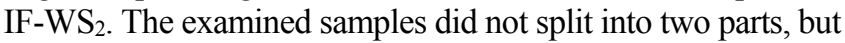
were just broken in the middle after the impact. This kind of material reaction to impact was expected, since the dominant failure mechanisms of woven fabric reinforced multi-layered composite structures, intended for ballistic protection, include delamination and fabric/matrix debonding, besides fiber breakage, matrix cracking and yarns pull-out $[19,20]$.

Table 12. Charpy impact test results

\begin{tabular}{|c||c|c||}
\hline Sample & $\begin{array}{c}\text { Absorbed impact } \\
\text { energy, } E(\mathrm{~J})\end{array}$ & $\begin{array}{c}\text { Impact toughness, } \\
U_{\mathrm{T}}\left(\mathrm{J} / \mathrm{cm}^{2}\right)\end{array}$ \\
\hline \hline aramid/phenolic resin/PVB & 1.73 & 66.5 \\
\hline $\begin{array}{c}\text { aramid/phenolic resin/PVB/1 wt\% } \\
\mathrm{WS}_{2}\end{array}$ & 2.12 & 81.5 \\
\hline
\end{tabular}

Composite 20-layer samples were tested by shooting with two kinds of bullets (.357 Magnum and $9 \mathrm{~mm}$ FMJ) according to standard NIJ 0101.06. The results of the ballistic shooting tests are shown in Table 13, showing back face deformations depths measured in ballistic clay after bullet impact [19].

Table 13. Ballistic testing results: BFD depth after shots

\begin{tabular}{|c|c|c||}
\hline Sample & $9 \mathrm{~mm}$ FMJ & .357 Magnum \\
\hline \hline aramid/PVB & 15.5 & Penetration \\
\hline aramid/PVB/IF-WS & 17 & 20.1 \\
\hline aramid/PVB/INT-WS & 13.8 & 14.3 \\
\hline
\end{tabular}

This test has confirmed the reinforcing effect of IF-WS and INT-WS 2 , resulting in up to $12 \%$ smaller BFD depths in composite with the nanotubes and in successful stopping the shots of both calibers, unlike the sample without nanoreinforcement.

The obtained results encourage further research in the area of application of inorganic fullerenes as a reinforcement of ballistic and other advanced composites. These results inspired researches from VTI to examine the possibility of reinforcing carbon fiber-based composites, presented in the following chapter.

\section{Nanoreinforced composites for aircraft construction}

Composite materials are used in the Military Technical Institute aviation projects for decades and are mastered by the technology of making complex shapes of composite structures. Unmanned, short and medium-range aircraft are produced from glass-plastic, Kevlar and carbon fibers in an epoxy-resin, in order to obtain a strong and lightweight structure of the aircraft. Within the recent research, composite materials based on carbon fibres and epoxy resins for use on aircraft were tested through comparative measurements of mechanical properties and analysis of the behavior of composite materials with nanoparticles and nanotubes of $\mathrm{WS}_{2}$ in the polymer matrix (epoxy resin modified by addition of PVB) and without nanoparticles, under conditions of static and dynamic load test.

In the research, the following materials were used: carbon unidirectional prepreg (areal density $450 \mathrm{~g} / \mathrm{m}^{2}$, produced by company HAUFLER Carbon fiber / Epoxy UD prepreg K63712), tungsten disulfide manufactured by Nanolub, ApNano, Israel (IF-WS 2 and INT-WS I $_{2}$ PVB Powder, manufactured by Kuraray GMBH, type Mowital $\mathrm{B} 45 \mathrm{H}$ and ethanol produced by Zorka Šabac. Agglomerated powders of IF-WS $\mathrm{W}_{2}$ and INT-WS $\mathrm{W}_{2}$ were subjected to ultrasonic dispersing and deagglomeration in ethanol with ultrasonic probe Badelin SonoPuls during 30 minutes. Subsequently, the container containing ethanol with tungsten disulphide was transferred to the magnetic stirrer, and during the mixing, an appropriate amount of PVB powder was added gradually.

After the impregnation of the prepregs, samples of laminar structures of 8 layers of carbon unidirectional prepreg were made, on which a PVB solution without $\mathrm{WS}_{2}$ was applied, as well as a PVB solution with IF-WS $\mathrm{W}_{2}$ and with INT-WS $\mathrm{S}_{2}$ for structural analysis and mechanical testing. They were subjected to pressure on the Belišće Thermal Press. The laminated composite structures were formed by a hot press molding technique under a defined pressure of 5 bar and at a temperature of $130^{\circ} \mathrm{C}$. The orientation of fibers was $90^{\circ}$. The obtained samples were cut into test specimens in accordance with ASTM D 3039 standards - tightening by placing composite samples between aluminum plates to avoid deformation and friction during cutting. Tabs - additives at the ends of the tubes entering the clamps are made of a glass fabric with epoxy resin, cut and glued to the test specimens. For tensile testing SHIMADZU SERVO PULSER was used, at tensile speed $1 \mathrm{~mm} / \mathrm{min}$ and pressure in the clamps 12.5bar. Test results are given in diagrams in Fig. 17 and in Table 14.

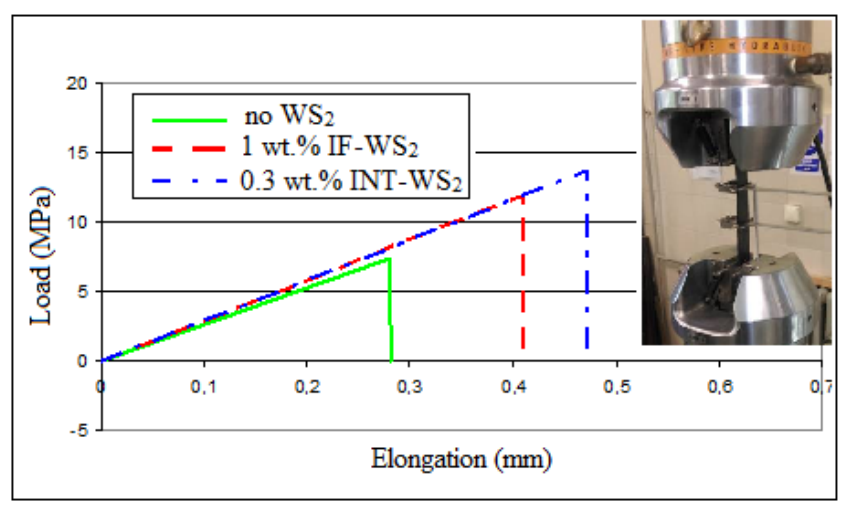

Figure 14. Tensile test results for examines composites 
Table 14. Force, tensile strength, modulus of elasticity and elongation of the tube

\begin{tabular}{|c|c|c|c|c||}
\hline & $\mathrm{F}_{\max }$ & $\mathrm{R}_{\mathrm{m}}$ & $\mathrm{E}$ & $\varepsilon$ \\
\hline \hline Sample & $\mathrm{kN}$ & $\mathrm{MPa}$ & $\mathrm{GPa}$ & $\%$ \\
\hline No nano-reinforcement & 0,60 & 7,43 & 4,62 & 0,15 \\
\hline IF -WS 2 1 wt. $\%$ & 0,95 & 11,87 & 4,61 & 0,22 \\
\hline INT- WS 2 0,3 wt. $\%$ & 1,07 & 13,69 & 5,18 & 0,30 \\
\hline
\end{tabular}

There is a significant improvement of mechanical properties observed: maximum force and elongation are increased approximately twice. In further research different fibres orientations will be examined and a wider spectrum of mechanical tests will be performed.

\section{Nanomaterials as constituents of energetic materials}

Metal powders can provide high amount of energy during combustion, which makes them attractive for usage as fuel components of rocket propellants, explosives and pyrotechnics. Chemical reactive metals are added to explosive compositions in order to raise energy of detonation. Although these metals do not react fast enough to participate in the reactions that occur in the zone of detonation, they can react with gaseous products of detonation and with the oxygen from surrounding air, and significantly increase power of shock wave of explosion. Significant increase of detonation energy can be achieved because of high amount of heat that is released through reaction of metal and products of detonation. Secondary, post-detonation combustion of metal fuel with detonation products can be used as a source of destructive energy in limited, enclosed space (it creates longer duration of overpressure and extra thermal damage) and this effect is pronounced at thermobaric explosive compositions [40-43]. Thermobaric explosives contain crystal high explosive, polymer binder, fuel component and oxidant. The most important characteristic of thermobaric explosives is the intensity of their thermobaric effect, which is the combination of overpressure and high temperature.

The most commonly used metal fuel is aluminum powder, which increases radius of explosion of aluminized explosives and raises the devastating effects. However, it is impossible to use total potential of added aluminum, because of high melting temperature of aluminum oxide, which leads to delay of aluminum particles ignition and low combustion rate [4345]. Aluminum powder becomes more reactive if its surface to mass ratio is higher. Range of sizes for particles of atomized aluminum which is used for production of explosives is below 40 micrometers.

Implementation of spherical aluminum nanoparticles (70 $\mathrm{nm}$ ) as a fuel component of cast PBX explosives is examined regarding its effect on energetic performance of thermobaric detonation [23]. Compositions were prepared containing octogen (HMX), amonium perchlorate (AP), aluminum (Al), magnesium $(\mathrm{Mg})$ and hydroxyl-terminated poly(butadiene) binder (HTPB). Quality, morphology and size of aluminum nanoparticles were observed by scanning electron microscope (SEM) JEOL JSM-6610 LV, under different magnification. SEM image of aluminum powder nano particles are presented in Figure 15. It is noticed that sizes of aluminum particles significantly differ. Since the form of particles is mostly spherical and since there is almost none agglomeration, it may be concluded that aluminum powder quality is very good.

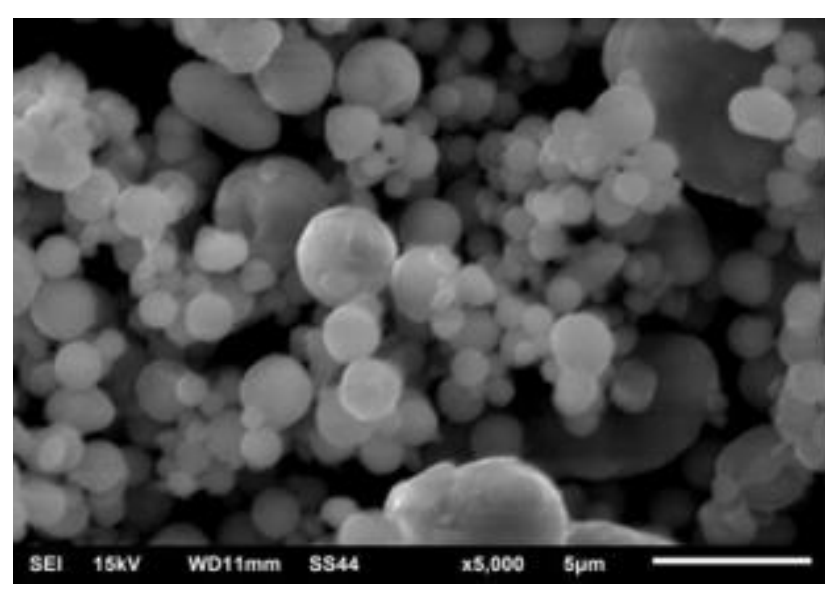

Figure 15. SEM image of aluminum nanoparticles under different magnifications

Four compositions were prepared (Table 15) by technological process of casting [23]: two with micro particle size aluminum and two with nanoparticle size aluminum (in those with nano-sized aluminum, half of the starting amount of the micron-sized aluminum was replaced by nano-sized). Cylindrical explosive charges/test samples were cast into 50 $\mathrm{mm}$ diameter explosive charges, with $500 \mathrm{~g}$ mass.

Table 15. Composition of investigated explosive charges

\begin{tabular}{|c||c|c|c|c|c|c||}
\hline \multirow{2}{*}{$\begin{array}{c}\text { Explosive compo- } \\
\text { sition }\end{array}$} & \multicolumn{6}{|c|}{ Content of components (wt.\%) } \\
\cline { 2 - 7 } & $\mathrm{HMX}$ & $\mathrm{AP}$ & $\mathrm{Al}(\mu \mathrm{m})$ & $\mathrm{Al}(\mathrm{nm})$ & $\mathrm{Mg}$ & $\mathrm{HTPB}$ \\
\hline \hline PBX -17/01 & 45 & 15 & 20 & $/$ & $/$ & 20 \\
\hline $\mathrm{PBX}-17 / 02$ & 45 & 15 & 10 & 10 & $/$ & 20 \\
\hline $\mathrm{PBX}-17 / 03$ & 40 & 15 & 24 & $/$ & 6 & 15 \\
\hline PBX -17/04 & 40 & 15 & 12 & 12 & 6 & 15 \\
\hline
\end{tabular}

Shock wave parameters of these explosives were determined by measuring overpressure in air using piezoelectric probes PCB 124B24A (high frequency pressure sensors, PCB Piezotronics, ICP $\AA$ free-field blast pressure "pencil" probes) at defined distances from the detonation centre: $3 \mathrm{~m}, 4 \mathrm{~m}, 5 \mathrm{~m}, 7 \mathrm{~m}$ and $9 \mathrm{~m}$. The explosive samples were placed on a wooden stand at $2 \mathrm{~m}$ height above ground, and the pressure transducers were placed on metal holders, also $2 \mathrm{~m}$ above ground. Average values of measured maximum overpressure, $P_{\max }$, and total impulse of the positive phase of the overpressure, I, are given in Table 16.

Table 16. Average values of overpressure and impulse of the shock wave at different distances

\begin{tabular}{||c|c|c|c|c|c||}
\hline \hline \multicolumn{2}{|c|}{ PBX composition } & $17 / 01$ & $17 / 02$ & $17 / 03$ & $17 / 04$ \\
\hline \hline \multirow{5}{*}{$P_{\max }, \mathrm{m} \cdot \mathrm{s}$} & $3 \mathrm{~m}$ & 0.582 & 0.577 & 0.529 & 0.558 \\
\cline { 2 - 6 } & $4 \mathrm{~m}$ & 0.345 & 0.336 & 0.317 & 0.348 \\
\cline { 2 - 6 } & $5 \mathrm{~m}$ & 0.236 & 0.234 & 0.215 & 0.246 \\
\cline { 2 - 6 } & $7 \mathrm{~m}$ & 0.135 & 0.141 & 0.127 & 0.145 \\
\cline { 2 - 6 } & $9 \mathrm{~m}$ & 0.105 & 0.109 & 0.100 & 0.113 \\
\hline \hline \multirow{5}{*}{$* 10^{3}$, bar's } & $3 \mathrm{~m}$ & 0.422 & 0.44 & 0.409 & 0.457 \\
\cline { 2 - 6 } & $4 \mathrm{~m}$ & 0.325 & 0.339 & 0.317 & 0.35 \\
\cline { 2 - 6 } & $5 \mathrm{~m}$ & 0.255 & 0.27 & 0.255 & 0.278 \\
\cline { 2 - 6 } & $7 \mathrm{~m}$ & 0.115 & 0.12 & 0.113 & 0.123 \\
\cline { 2 - 6 } & $9 \mathrm{~m}$ & 0.262 & 0.264 & 0.263 & 0.286 \\
\hline
\end{tabular}

It can be observed that there is almost no difference in $\mathrm{P}_{\max }$ for compositions with higher amount of HTPB between samples with nanoparticle aluminum and samples without it. For compositions with lower amount of polymer binder and 
with $\mathrm{Mg}$ there is a difference in favor of composition PBX 17/04composition with nanoaluminum. Measured overpressures for this composition are higher for $5-14 \%$, which depends on the distance of measuring spot from the centre of detonation. Impulse values are higher at $9 \mathrm{~m}$ than at $7 \mathrm{~m}$ measuring distance, as a consequence of superposition of the primary shock wave and the reflected wave. Values of impulses are higher for samples with nanometer aluminum, for all measuring distances. There is an increase of impulse up to $\sim 12 \%$ for composition with nanoaluminum (PBX 17/04 compared to PBX 17/03, at the distance 3 $\mathrm{m}$ away from centre of detonation).
Thermal effect of detonations was tracked using thermal imaging camera FLIR 7200 SC placed $50 \mathrm{~m}$ from the sample. Measuring areas (MA) on IR recordings were chosen as follows: MA 1 represents the centre of detonation. MA 2 and 3 , regarding the centre of detonation, are placed: MA 2: $90 \mathrm{~cm}$ above the centre of the detonation, MA 3: at the angle of $45^{\circ}$ to the line that 1 and 2 create, $90 \mathrm{~cm}$ away from MA 2[23]. For two selected tested PBX compositions, time diagrams of registered temperature are shown in Figure 16.
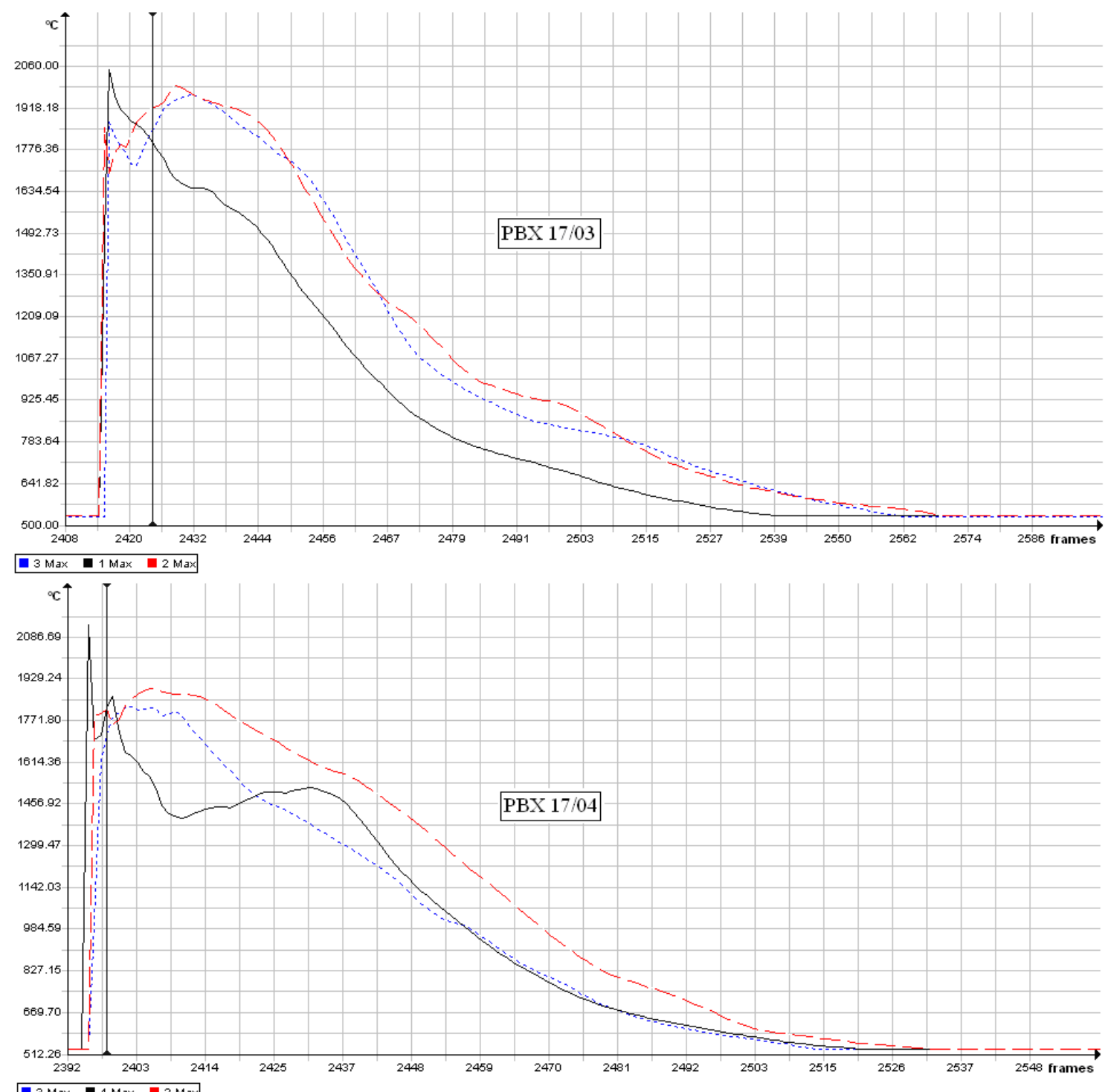

- 3 Max 1 Max 2 Max

Figure 16. Temperature-time dependence at MA 1, 2 and 3 for sample PBX 17/03 and PBX 17/04

From the shown diagrams it may be observed that registered temperature-time dependences are very similar. Area of post-detonation combustion of aluminum powder is noticed, i.e. aluminum and magnesium, and in that area temperature value is between 1750 and $1900^{\circ} \mathrm{C}$. If we observe the duration while temperature has higher value than some chosen temperature, the effect of nanoaluminum on the process of post-detonating combustion can be noticed. As frequency value is $1412 \mathrm{~Hz}$, duration of single frame is $7.082 * 10^{-4} \mathrm{~s}$. Thus, it is calculated that temperatures are higher than, for example $700^{\circ} \mathrm{C}$, during: $75.78 \mathrm{~ms}$ for sample of PBX17/03 and $62.32 \mathrm{~ms}$ for sample of PBX 17/04. Therefore, compositions with nano-sized aluminum have shorter phase of post-detonating combustion, i.e. nanometer aluminum burns faster. This is not desirable for this kind of explosive, so this gives reason for further research in order to achieve a good balance between improvements of shock wave power and the duration of post-detonation combustion of components and detonation products.

At the temperature range between $1500-2500^{\circ} \mathrm{C}$ and frequency $10 \mathrm{kHz}$, temperature maximums were estimated at approximately $3400^{\circ} \mathrm{C}$ [23]. That is in accordance with expectation and previous results for similar samples, i.e. for similar compositions containing aluminum or aluminum and magnesium, where maximum recorded temperatures were above $3300^{\circ} \mathrm{C}$, which was confirmed using optical pyrometer 
[40-42]. Actually, added nanoparticles of aluminum do not affect maximum temperatures, they are affected by the composition; but do affect the duration of post-detonation combustion.

The observed results encourage further research regarding the optimum ratio of nano and micron sized aluminum that provides best shock wave performance and satisfying thermal effect. Researches are being done in VTI with nanoaluminum as a fuel component of composite rocket propellants and pyrotechnic mixtures, but also other nanosized ingredients of energetic materials are planned to be examined.

\section{Conclusion}

Military Technical Institute keeps up with the modern researches in the field of nanotechnologies when it comes to applications of nanomaterials with special properties in defense technologies. Small concentrations of specific nanoparticles $(0.3 \mathrm{wt} . \%-3$ wt.\%) provide significant enhancement of thermo-mechanical properties and protective performance when added to materials for CBRN protection, nanomodified polymer coatings and camouflage paints, composite structures for military aircrafts, ballistic protection composites, and enhance the energetic performance of explosive materials.

In the area of CBRN protection two methods for $\mathrm{TiO}_{2}$ nanoparticles synthesis (known for their photocatalytic activity) and their deposition on the textile samples were investigated in order to obtain self-decontaminating textile. The ability of $\mathrm{TiO}_{2}$ to decompose CW agents is promising although further improvements in terms of efficacy are needed. Since the treatment of the textiles by nano $\mathrm{TiO}_{2}$ sols diminishes their mechanical properties, nano $\mathrm{SiO}_{2}$ particles were used to reinforce the tested textile. Rubber materials for the use in CBRN protection were treated with IF-WS nanoparticles and an improvement of the protective and mechanical properties has been observed.

Nanocomposites of enhanced thermo-mechanical and tribological properties poly(vinyl butyral)/tungsten disulfide were prepared, i.e. PVB was reinforced by adding a small quantity of $\mathrm{IF}_{-} \mathrm{WS}_{2}$ nanoparticles trough different techniques of nanofiller deagglomeration and dispersion. Glass transition is increased after the addition of nanoparticles, as well as modulus of hardness and elasticity. Friction coefficient was decreased significantly. Tensile properties were enhanced as well.

Physical-mechanical properties of polymeric coating used for military camouflage purposes were enhanced by adding IF-WS ${ }_{2}$ nanoparticles in small concentrations: the hardness, abrasion resistance and the resistance to steel balls impact were improved, the rheological behavior is in accordance with expectations, and the coatings are persistent in all the used aggressive media: water, salt water, mineral oil and a mixture of isooctane and benzene. Spectrophotometric examinations indicate that dyes with nanoparticles addition have better camouflage qualities and the difference between each pair of samples is not visible to the observer's eye.

Addition of small concentrations of IF-WS $\mathrm{W}_{2}$ and INT-WS has a favorable effect on the mechanical and ballistic resistance of the composite materials for ballistic protection. Significant improvement of anti-ballistic performance has been observed for the samples of composite structures based on aramid fabric impregnated with PVB reinforced with INT-WS 2 : better thermo-mechanical resistance, higher impact toughness, absorbed energy, and smaller depth of backface deformation.
The same nanofillers were used as reinforcement of carbon fibre/epoxy composite and improvement of tensile properties were achieved.

Addition of nano-sized aluminum has shown positive effect on energetic performances of thermobaric PBX explosive: overpressures are higher for $5-14 \%$, total impulses have up to $11.7 \%$ higher values. Thermal imaging records show similar values of maximum measured temperatures but influence of nanoaluminum is obvious when it comes to temperature-time dependence: compositions with nanometric aluminum have shorter phase of post-detonating combustion, i.e. nanoparticle aluminum reacts faster.

Researches presented in this survey gave promising results and encourage the use of the examined nanomaterials in future applications. These findings also give us a reason to proceed with the researches in order to optimize the concentrations of used nanoparticles, the technology of their incorporation in composites, coatings and other materials. Having in mind that very good results have been obtained with low nanoparticles concentrations used in this presented research, it would be interesting to examine the possibility of using even lower concentrations of nanofiller, in order to retain good properties at lower consumption of expensive nanomaterials.

\section{Acknowledgement}

The authors thank to the Ministry of Education, Science and Technological Development of the Republic of Serbia for the financial support of the research through the project TR 34034 - "Application of nanomaterials in the improvement of respiratory and percutaneous protection under conditions of ecological imbalance caused by radioactive, chemical and biological contamination" (2010-2018).

\section{References}

[1] Defense Nanotechnology Research and Development Programs, Department of Defense, U.S. 2005.

[2] PORTER,J., MORRIS,J., ALDERSON,N.: DoD Perspective and Nanotechnology, in Proceedings of 2008 NSF Nanoscale Science and Engineering Grantees Conference, 03-05. December, 2008, NSF Arlington, VA

[3] LELE,A.: Role of Nanotechnology in Defence, Strategic Analysis, DOI: 10.1080/09700160802518700, March 2009, Vol.33, No.2, pp.229-241.

[4] De NEVE,A.: Military Uses of Nanotechnology and Converging Technologies: Trends and Future Impacts, Royal High Institute for Defence, Center for Security and Defence Studies, Focus Paper 8 (http://www.irsd.be/website/images/livres/focuspaper/FP08.pdf, accessed $27^{\text {th }}$ September, 2018)

[5] BOURQUE,J.M.: Kryron Global, LLC, Solid composition having enhanced physical and electrical properties, United States Patent Application Publication No.: US 2010/0193749 A1, 2010.

[6] SENIĆ,Ž., BAUK,S., SIMIĆ,D., VITOROVIĆ-TODOROVIĆ,M., MARKOVIĆ,T., RAJIĆ,D.: The preliminary comparative analysis of different routes for $\mathrm{TiO}_{2}$ nanoparticles synthesis and their deposition on textiles, The methyl-orange degradation and VX detoxication study, Digest Journal of Nanomaterials and Biostructures, ISSN: 1842-3582, 8, 2013, pp.711-719,

[7] SENIĆ,Ž., $\quad$ BAUK,S., $\quad$ VITOROVIĆ-TODOROVIĆ,M., SAMOLOV,A., RAJIĆ,D.: Application of TiO2 nanoparticles for obtaining self-decontaminating smart textiles, Scientific Technical Review, ISSN 1820-0206, 2011, 2011, Vol.61, No.3-4, pp.63-72.

[8] VITOROVIĆ-TODOROVIĆ,M., SIMIĆ,D.: Can we use nanotechnologies to develop self-decontaminating CBRN protective suits?, Book of Abstracts / COST MP1402 Scientific Workshop "ALD and related ultra-thin film processes for advanced devices", ISBN 97886-81405-22-2, 29-30. August, 2017, Belgrade, pp.14. 
[9] BAUK,S., SENIĆ,Ž., VITOROVIĆ-TODOROVIĆ,M., SIMIĆ,D., RADOJKOVIĆ,A., MARKOVIĆ,T., RAJIĆ,D.: Methyl orange degradation and VX-detoxication of nano-TiO2 treated standard military textiles, 8th International Conference on Chemical Societes of South-Eastern Europe, BS-CB P11, Belgrade 2013, COBISS.SR-ID 199136780.

[10] BAUK,S., VITOROVIĆ-TODOROVIĆ,M., MAZANEC,K., SENIĆ,Ž., PAJIĆ,N., RAJIĆ,D.: Decomposition of organic dyes and CWA simulants by nano TiO2-treated standard military textiles, 5 th International Conference on Defensive Technologies OTEH 2012, 1819. September 2012, Belgrade, SERBIA, Proceedings, ISBN 978-8681123-58-4, pp. 693-697.

[11] LAZIĆ, D., SIMIĆ, D., SAMOLOV, A.: Effect of nano-IF-WS ${ }_{2}$ and INT-WS ${ }_{2}$ on physical-mechanical and camouflage properties of military coatings, Book of Abstracts / COST MP1402 Scientific Workshop "ALD and related ultra-thin film processes for advanced devices", 29-30. August, 2017, Belgrade, SERBIA, ISBN 978-8681405-22-2, p.30.

[12] LAZIĆ,D., SIMIĆ,D., SAMOLOV,A.: Effect of $I F-W S_{2}$ nanoparticles addition on physical-mechanical and rheological properties and on chemical resistance of water-based paints, The $18^{\text {th }}$ annual conference YUCOMAT 2016, 05-10. September 2016, Herceg Novi, MONTENEGRO, ISBN 978-86-919111-1-9, p.87.

[13] LAZIĆ,D., SIMIĆ,D., SAMOLOV,A.: Effect of IF-WS nanoparticles $^{2}$ addition on physical-mechanical and rheological properties and on chemical resistance of polymeric coating and polyurethane paint, $7^{\text {th }}$ International Scientific Conference on Defensive Technologies OTEH 2016, 06-07. October 2016, Belgrade, SERBIA, Proceedings, ISBN 978-86-81123-82-9, pp.609-613.

[14] LAZIĆ,D., SIMIĆ,D., SAMOLOV,A., JOVANOVIĆ,D.: Properties of standard polymeric and water-based coatings for military camouflage protection with addition of inorganic fullerene-like tungsten disulphide $\left(I F-W_{2}\right)$ nanoparticles, Scientific Technical Review, ISSN 1820-0206, 2017, Vol.67, No.1, pp. 38-44

[15] SIMIĆ,D.M., STOJANOVIĆ,D.B., KOJOVIĆ,A., DIMIĆ,M., USKOKOVIĆ,P.S., ALEKSIĆ,R.: Tribomechanical and thermal properties of PVB thin films reinforced with nano IF-WS , Book of Abstracts / COST MP1402 Scientific Workshop "ALD and related ultra-thin film processes for advanced devices", 29-30. August, 2017, Belgrade, SERBIA, ISBN 978-86-81405-22-2, p. 28, COBISS.SR-ID 242328076 (the workshop is organized as a satellite event of VI International School and Conference on Photonics PHOTONICA '17).

[16] SIMIĆ,D.M., STOJANOVIĆ,D.B., KOJOVIĆ,A., DIMIĆ,M., TOTOVSKI,LJ., USKOKOVIĆ,P.S., ALEKSIĆ,R.: Inorganic fullerene-like IF-WS2/PVB nanocomposites of improved thermomechanical and tribological properties, Materials Chemistry and Physics, doi: 10.1016/j.matchemphys.2016.09.060, 2016, 184, pp.335344.

[17] SIMIĆ,D.M., STOJANOVIĆ,D.B., DIMIĆ,M., TOTOVSKI,LJ., BRZIĆ,S., USKOKOVIĆ,P.S., ALEKSIĆ,R.: Preliminary analysis of the possibility of preparing $P V B / I F-W S_{2}$ composites. Effect of nanoparticles addition on thermal and rheological behaviour of $P V B$, Scientific Technical Review, ISSN 1820-0206, 2016, Vol. 66, No. 4, pp.15-21.

[18] SIMIĆ,D.M., STOJANOVIĆ,D.B., KOJOVIĆ,A., TOTOVSKI,LJ., BURZIĆ,Z., USKOKOVIĆ,P.S., ALEKSIĆ,R.: Ultrasonic deagglomeration of tungsten disulfide nanoparticles $\left(W S_{2}\right)$ in different solvents for enhancing nanomechanical properties in poly (vinyl butyral) (PVB) nanocomposites, The $16^{\text {th }}$ annual conference YUCOMAT 2014, 01-05. September 2014, Herceg Novi, MONTENEGRO, p.101.

[19] SIMIĆ, D.: "Balistički hibridni nanokompozitni materijali ojačani neorganskim fulerenima", doktorska disertacija, Tehnološko-metalurški fakultet, Univerzitet u Beogradu, SRBIJA, 09.11.2017.

[20] SIMIĆ,D.M., STOJANOVIĆ,D.B., BRZIĆ,S.J., TOTOVSKI,LJ., USKOKOVIĆ,P.S., ALEKSIĆ,R.R.: Aramid hybrid composite laminates reinforced with inorganic fullerene-like tungsten disulfide nanoparticles, Composites: Part B: Engineering, ISSN 1359-8368, 2017, 123, pp.10-18, , http://dx.doi.org/10.1016/j.compositesb. 2017.05.002, IF (2016) $=4.727$

[21] SIMIĆ,D.M., STOJANOVIĆ,D.B., TASIĆ,A., USKOKOVIĆ,P.S., ALEKSIĆ,R.: Effect of $I F-W S_{2}$ nanoparticles addition on thermorheological and mechanical behavior of aramid/phenolic resin/PVB composite material, The eighteenth annual conference YUCOMAT 2016, 05-10. September 2016, Herceg Novi, MONTENEGRO, ISBN 978-86-919111-1-9, p.89.
[22] SIMIĆ,D.M STOJANOVIĆ,D.B.,

TOTOVSKI,LJ., USKOKOVIĆ,P.S., ALEKSIĆ,R.: Aramid/PVB/WS 2 advanced composite material thermo-rheological properties, 29. Međunarodni kongres o procesnoj industriji PROCESING 16, 02-03. June 2016, Belgrade, SERBIA, ISBN 978-86-81505-81-6, pp.113-125.

[23] SIMIĆ,D.M., $\quad$ DIMITRIJEVIĆ,I.D., $\quad$ SIROVATKA,R.S., KNEŽEVIĆ,D.M., MIŠKOVIĆ,K., TOTOVSKI,Lj.: Thermobaric performance of cast $P B X$ with nanosized aluminium, 49th International Annual Conference of the Fraunhofer ICT, Karlsruhe, GERMMANY, 26-29. June 2018, pp.131/1-131/12

[24] TENNE,R., MARGULIS,L., GENUT,M., HODES,G.: Polyhedral and Cylindrical Structures of Tungsten Disulfide, Nature, 1992, 360, pp.444-446.

[25] TEVET,O., VON-HUTH,P., POPOVITZ-BIRO,R., ROSENTSVEIG,R., WAGNER,H.D., TENNE,R.: Friction mechanism of individual multilayered nanoparticles, Proc. Natl. Acad. Sci. U.S.A., 2011, 108, pp.19901-19906.

[26] FANG,X.: Large Scale Manufacturing of IF-WS2 Nanomaterials and Their Application in Polymer Nanocomposites, doctoral thesis, University of Exeter, Devon, UK, 2013.

[27] ZHU, Y. Q.. SEKINE, T., KIEREN, B. S., FIRTH, S., TENNE, R., ROSENTSVEIG, R., KROTO, H. W., WALTON, D. R.: Shock-Wave Resistance of $\mathrm{WS}_{2}$ Nanotubes, J. Am. Chem. Soc. 2003, 125, pp.13291330.

[28] NEMES,P.I.: Nanocomposite coatings for anticorrosion protection of some metals, $\mathrm{PhD}$ Thesis, Universitatea Babeş-Bolyai, Cluj Napoca, ROMANIA, 2013.

[29] EIDELMAN,O., FRIEDMAN,H., ROSENTSVEIG,R., MOSHKOVITH,A. PERFILIEV,V., COHEN,S.R., FELDMAN,Y., RAPOPORT,L., TENNE,R.: Chromium-rich coatings with $\mathrm{WS}_{2}$ nanoparticles containing fullerene-like structure, NANO: Brief Reports and Reviews, 2011, Vol.6, No.4, pp.313-324, DOI: 10.1142/S1793292011002755

[30] UDDIN,M.J.: Photoactive $\mathrm{TiO}_{2}$ films on cellulose fibres: synthesis and characterization, J. Photochem. Photobiol. Chem. A, 2007, 189, No.23, pp.286-294

[31] QI,K.: Facile preparation of anatase/SiO $\mathrm{O}_{2}$ spherical nanocomposites and their application in self cleaning textiles, J. Mater. Chem., 2007, 17 , pp.3504-3508

[32] VITOROVIĆ-TODOROVIĆ,M., BAUK,S.: Uticaj završne obrade nanočesticama tekstilnih i gumiranih materijala ugrađenih u sredstva NHB zaštite, Tehnički izveštaj reg. broj: VTI-04-01-1179, Vojnotehnički institut, Beograd, SRBIJA, 2017.

[33] ISMAIL,I.N., ISHAK,Z.A.M., JAAFAR,M.F., OMAR,S., ZAINAL ABIDIN,M.F., AHMAD MARZUKI,F.: Thermo-mechanical properties of toughened phenolic resol resin, Solid State Science and Technology, 2009, Vol.17, No.1, pp.155-165.

[34] STOJANOVIĆ,D.B., ZRILIĆ,M., JANČIĆ-HEINEMANN,R., ZIVKOVIĆ,I., KOJOVIĆ,A., USKOKOVIĆ,P.S., ALEKSIĆ,R.: Mechanical and anti-stabbing properties of modified thermoplastic polymers impregnated multiaxial p-aramid fabrics, Polym. Adv. Technol. 2013, 24, pp.772-776, DOI: 10.1002/pat.3141

[35] Obradović, V., Stojanović, D.B., Jokić, B.: Nanomechanical and antistabbing properties of Kolon fabric composites reinforced with hybrid nanoparticles. Compos Part B, 2017, 108, pp.143-152.

[36] TIAN,M.A., TAO,Z., PENGGANG,G., JIANCHUN,Z.: Synthesis and properties of ultrahigh molecular weight polyethylene/WS nanoparticle fibre for bullet-proof materials, Chin Sci Bull, 2013, Vol.58, No.8 pp.945-948, doi: 10.1007/s11434-012-5555-7

[37] REDDY,C., ZAK,A., ZUSSMAN,E.: $W S_{2}$ nanotubes embedded in PMMA nanofibres as energy absorptive material, J Mater Chem, 2011, 21(40):16086_93. DOI: 10.1039/c1jm12700d

[38] XU,F., KOBAYASHI,T., YANG,Z., SEKINE,T., CHANG,H., WANG,N., XIA, Y., ZHU,Y.: How the Toughest Inorganic Fullerene Cages Absorb Shockwave Pressures in a Protective Nanocomposite: Experimental Evidence from Two In Situ Investigations, ACS Nano, 2017, pp.8114-8121.

[39] GENUTH,I.; YAFFE,T.: Protecting the Soldiers of Tomorrow; http://www.isracast.com/article.aspx?id=28 (accessed August 10, 2016).

[40] SIMIĆ,D., ANDJELIĆ,U., KNEŽEVIĆ,D., SAVIĆ,K., DRAGANIĆ,V., SIROVATKA,R., TOMIĆ,Lj.: Thermobaric effects of cast composite explosive of different charge mass and dimensions, Central European Journal of Energetic Materials, ISSN 1733-7178, 
2016, Vol.13, No.1, pp.161-182

[41] SIMIĆ,D., POPOVIĆ,M., SIROVATKA,R., ANĐELIĆ,U.: Influence of Cast Composite Thermobaric Explosive Compositions on Air Shock Wave Parameters, Scientific Technical Review, ISSN 1820 0206, 2013, Vol.63, No.2, pp.63-69,

[42] SIMIĆ,D.: Liveni termobarični PBX eksplozivi, Monografska serija, Naučnotehničke informacije, Vojnotehnički institut, ISSN 1820-3418, ISBN 978-86-81123-78-2, Beograd, 2016, Vol.53, No.2,

[43] CHAN,M.L., MEYERS,G.W.: ADVANCED THERMOBARIC EXPLOSIVE COMPOSITIONS, US Patent No: US 6,955,732 B1, 2005.
[44] ANTIĆ,G., DŽINGALAŠEVIĆ,V.: Characteristics of cast $P B X$ with aluminium, Scientific Technical Review, ISSN 1820-0206, 2006, Vol.LVI, No.3-4, pp.52-58.

[45] CHAN,M.L., TURNER,A.D.: High energy blast explosives for confined spaces, US Patent No.6, 969,434, 2002.

\title{
Nanotehnologije u vojnoj primeni - pregled novijih istraživanja u Vojnotehničkom institutu
}

\begin{abstract}
Armije moćnih svetskih sila već primenjuju dostignuća nanonauke i pružaju podršku istraživanjima u oblasti nanotehnologije. Ovaj rad predsravlja pregled skorašnjih istraživanja u oblasti primene nanomaterijala u odbrambenim tehnologijama, sprovedenih u Vojnotehničkom institutu u Beogradu u Srbiji. Prikazana istraživanja su pokrila najvažnije rezultate dobijene u sledećim oblastima: NHB zaštita, nanomodifikovani polimerni premazi i maskirne boje, kompozitne strukture za vojne letelice, kompoziti za balističku zaštitu i energetski materijali. Istraživanja su dala obećavajuće rezultate u svim navedenim poljima i ohrabruju primenu nanomaterijala u budućnosti.
\end{abstract}

Ključne reči: nanotehnologija, nanomaterijali, nanočestice, nanovlakno, polimerni premazi, vojna primena, NHB zaštita, balistička zaštita, maskiranje, energetski materijali.

\section{Nanotechnologie dans l'utilisation militaire - vue d'ensemble des recherches les plus récentes à l'Institut militaire technique}

Les armées de grandes forces mondiales appliquent déjà les réalisations de nanotechnologie et aident les recherches dans le domaine de la nanotechnologie. Ce papier présente une vue d'ensemble sur les récentes recherches dans le domaine de l'utilisation des nanomatériaux chez les technologies de défense conduites à l'Institut militaire technique à Belgrade, Serbie. Les recherches présentées ont couvert les plus importants résultats obtenus dans les domaines suivants : protection $\mathrm{ABC}$, enduits polymères modifiés par nanotechnologie, couleurs de camouflage, structures composites pour les aéronefs militaires, composites pour la protection balistique et les matériaux énergétiques. Les recherches ont donné les résultats prometteurs dans tous les champs cités et ils encouragent l'utilisation de nanomatériaux dans l'avenir.

Mots clés: nanotechnologie, nanomatériaux, nanoparticules, nanofibre, enduits polymères, utilisation militaire, protection ABC, protection balistique, camouflage, matériaux énergétiques.

\section{Нанотехнологии в военных применениях - обзор последних исследований в военно-техническом институте}

\footnotetext{
Войска мощных мировых держав уже применяют достижения нанотехнологий и поддерживают исследования в области нанотехнологий. В этом документе описывается обзор последних исследований в области использования наноматериалов в оборонных технологиях, проводимых в Военно-техническом институте в Белграде в Сербии. Представленные исследования охватывали наиболее важные результаты, полученные в следующих областях: защита от (ЯХБ) опасности, наномодифицированные полимерные покрытия и маскирующие краски, композитные структуры для военных самолётов, композиты для баллистической защиты и энергетические материалы. Исследования дали многообещающие результаты во всех этих областях и поощряют использование наноматериалов в будущем.
}

Ключевые слова: нанотехнология, наноматериалы, наночастицы, нановолокна, полимерные покрытия, военные применения, защита от ядерной, химической или биологической (ЯХБ) опасности, баллистическая защита, маскирование, энергетические материалы. 